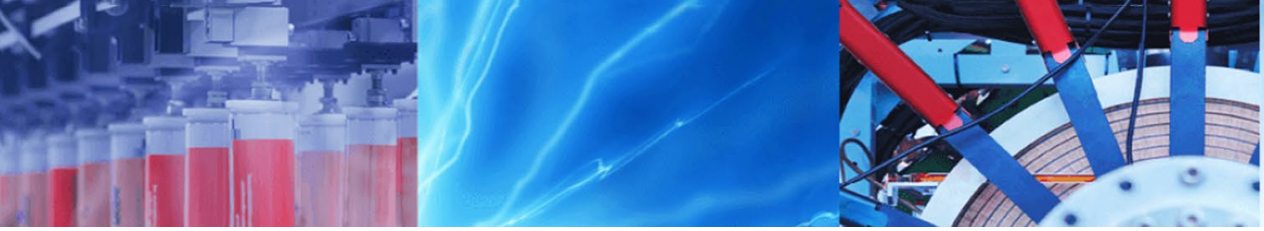

Research Article

\title{
Environmental and health risks of metal-contaminated soil in the former tannery area of Hazaribagh, Dhaka
}

\author{
Al-Mizan ${ }^{1}$ (D) Md Ariful Islam Juel ${ }^{1,2} \cdot$ Md Shahin Alam $^{3} \cdot$ John Pichtel $^{3} \cdot$ Tanvir Ahmed $^{4}$
}

Received: 9 July 2020 / Accepted: 13 October 2020 / Published online: 28 October 2020

(c) Springer Nature Switzerland AG 2020

\begin{abstract}
Soil and plant samples collected from Hazaribagh, the former tannery area in Dhaka, Bangladesh, were analyzed for heavy metals $(\mathrm{Cr}, \mathrm{Pb}, \mathrm{Ni}, \mathrm{Zn}, \mathrm{Cd}$, and $\mathrm{Cu})$. The pollution and health risks of the metals were assessed with commonly used indicators. The mean soil $\mathrm{Cr}$ concentration was $4321 \mathrm{mg} / \mathrm{kg}$ (range 294-23,148 mg/kg). Most sites had a moderate to high degree of contamination and were classified as extremely polluted (Pollution Load Index $>1$ ). The non-carcinogenic hazard index was greater than 1 for $\mathrm{Pb}$ and $\mathrm{Cr}$ for both children and adults, which indicates considerable non-cancer health risk. The combined cancer risks for $\mathrm{Pb}$ and $\mathrm{Cr}$ exceeded the allowable range of $1 \times 10^{-6}-1 \times 10^{-4}$ for most sites (8 out of 11 sites in the case of adults, all sites in the case of children) with $\mathrm{Cr}$ being the dominant contributor and oral ingestion the primary pathway. The cancer and non-cancer risks for children were 26- and 3-fold higher, respectively, than for adults. Among all heavy metals, $\mathrm{Pb}$ and $\mathrm{Zn}$ were the most susceptible to leaching and becoming mobilized in groundwater. Concentrations of $\mathrm{Pb}, \mathrm{Cr}$, and $\mathrm{Zn}$ in edible parts of vine spinach (Basella alba) exceeded safe limits. However, $\mathrm{Pb}$ and $\mathrm{Cu}$ showed significant accumulation in plants (Mean Transfer Factor of 1.064 and 0.94 , respectively, for $\mathrm{Pb}$ and $\mathrm{Cu}$ ), while $\mathrm{Cr}$ exhibited relatively lower bioavailability. The spatial distribution of heavy metal contamination and associated risks presented in this study will allow policymakers to pinpoint areas of intervention for remediation.
\end{abstract}

Keywords Cancer risk · Chromium · Non-carcinogenic risk $\cdot$ Risk assessment $\cdot$ Soil pollution

\section{Introduction}

Heavy metal contamination of soil is a significant hazard and can impart adverse impacts on human health and the environment [1, 2]. Both natural and anthropogenic sources contribute to heavy metal pollution $[3,4]$. Natural sources such as volcanic eruptions and weathering of rocks enrich and mobilize heavy metals on the earth's surface. However, anthropogenic activities, especially over the past few decades, have been documented as the key contributor to increased concentrations of heavy metals in soil and water. Chemical industries, tanneries, mining and smelting, iron and steel industries, agriculture, waste disposal, battery recycling and oil refining have been responsible for emissions of heavy metals to various environmental compartments [5-10].

In Bangladesh, tannery industries have been at the forefront of environmental pollution for decades. The hub of tanning industries was established in Hazaribagh, Dhaka, about 70 years ago, prior to establishment of relevant environmental regulations. Approximately 185 tanneries operated in the area, which discharged untreated liquid effluent and generated hazardous solid waste without requirements for effluent treatment and waste management [11].

Al-Mizan, almizan@le.kuet.ac.bd; almizanbcsir@gmail.com|'Department of Leather Engineering, Khulna University of Engineering and Technology, Khulna 9203, Bangladesh. ${ }^{2}$ Department of Civil and Environmental Engineering, The University of North Carolina at Charlotte, Charlotte, NC 28223, USA. ${ }^{3}$ Department of Environment, Geology and Natural Resources, Ball State University, Muncie, IN 47306, USA. ${ }^{4}$ Department of Civil Engineering, Bangladesh University of Engineering and Technology, Dhaka 1000, Bangladesh. 
A wide range of chemicals is required for leather processing; those of greatest concern are chromium sulfate, tannins, pigments, dyes, lime, salt of ammonia, bactericides, and fungicides [12-14]. During leather processing at the Hazaribagh tanning industries, large quantities of solid and liquid wastes were generated. It is estimated that, on average, about $22,000 \mathrm{~m}^{3}$ of highly toxic effluents were discharged daily into low-lying areas, lagoons and canals, which ultimately entered the Buriganga River $[14,15]$. In addition, 1.25 metric tonnes of chromium were generated daily by these industries, from which 0.35 metric tonnes may have settled into the surrounding low-lying areas of Hazaribagh [15]. Besides tanneries, over 70 paint and glue industries were located in Hazaribagh, discharging $504,000 \mathrm{~m}^{3}$ of untreated effluents annually, further aggravating local environmental conditions [12]. The Bangladesh Government has only recently relocated the scattered tanneries from Hazaribagh to a separate industrial estate in Savar, Dhaka, where specialized facilities have been designed to treat liquid effluents and manage solid waste. However, uncontrolled discharge into water bodies, canals, and open spaces in Hazaribagh over several decades have likely enriched the pollutants in soil and vegetation and still poses a risk to human health and the local environment [12]. Heavy metals can accumulate and become immobilized via chemical precipitation and adsorption reactions and occur as highly resistant compounds in soil [3]. In certain circumstances, heavy metals may be transported from soil to surface water and groundwater through runoff or percolation. Metals can also be taken up by plants, accumulate, and eventually enter into the human body $[4,16]$.

Recent studies have revealed that $90 \%$ of heavy metal intake in the human body is attributed to the consumption of plants [4, 17]. Excessive exposure and accumulation of heavy metals in the body can result in acute and chronic health problems including cardiovascular disease, bone damage, kidney dysfunction, cancer as well as gastrointestinal, muscular, reproductive, neurological and genetic damages $[1,6,18]$.

Research has been conducted in the Hazaribagh district to assess heavy metal contamination of water, soil, and sediment of the Buriganga River, which flows adjacent to the area [2,19-21]. Few studies, however, have assessed heavy metal content in plants occurring on the embankment or the effluent discharge channels to the river Buriganga [22, 23]. Earlier work has highlighted soil and groundwater pollution within the tannery establishment $[11,13,15]$. However, contact with contaminated soil may pose direct risks to human health, and a holistic picture of the risks of the area is yet to be developed. This area has been earmarked for residential development with green spaces, along with medical and educational institutions and other facilities [13]. Those living and working in this area may experience accidental exposure to heavy metals via ingestion, inhalation, or dermal contact. Therefore, the current state of heavy metal contamination and its associated risks need to be assessed in order to formulate a reclamation strategy and for mitigating adverse human health effects and environmental damage.

The primary objective of this study is to assess the present status of heavy metal contamination in the Hazaribagh area and its potential impact on the local environment. We used indices such as ecological risk factor $(E r)$, ecological risk index $(R I)$, pollution load index $(P L I)$, contamination factor $(C F)$, geo-accumulation index $\left(I_{\text {geo }}\right)$, degree of contamination $\left(C_{\text {deg }}\right)$, transfer factor (TF), and estimated non-carcinogenic and carcinogenic risks to understand the hazard posed by heavy metal accumulation to the surrounding environment and human health. The extent of potential leaching of heavy metals was assessed for predicting groundwater pollution. An assessment of human health risks via the consumption of vegetables grown on the contaminated sites was also done.

\section{Materials and methods}

\subsection{Study area and sampling}

The study area is the former tannery campus of Hazaribagh, located in southwestern Dhaka (Fig. 1). The campus encompasses an area of $0.55 \mathrm{~km}^{2}$ and has a population density of 32,856 per $\mathrm{km}^{2}$ [24]. Untreated heavy metalenriched solid waste had been disposed and stored in and adjacent to the former Hazaribagh tannery estate for several decades. Effluent discharged from the tannery were sometimes temporarily stored in ponds before being conveyed to the Buriganga River [12]. The soil of Hazaribagh is basically non-calcareous alluvium having a silty texture [22]. The major elements (in terms of oxides) in the topsoil $(0-0.5 \mathrm{~m})$ are $\mathrm{SiO}_{2}(22.9 \%), \mathrm{CaO}(20 \%), \mathrm{SO}_{3}(7 \%)$, and $\mathrm{Al}_{2} \mathrm{O}_{3}$ $(6.8 \%)$, where the $\mathrm{SiO}_{2}$ fraction increases more than twofold in the deeper strata [25].

Eleven soil sampling locations were selected in the Hazaribagh, Dhaka (Fig. 1). All soil samples were collected to a depth of 0 to $20 \mathrm{~cm}$ and placed in clean plastic bags. Three replicate samples were collected from each site. Vine spinach (Basella alba) samples were collected from three representative sampling sites (Table 1). Vine spinach is the most commonly cultivated vegetable in the study area and was therefore selected as an indicator species for metal uptake assessment. 

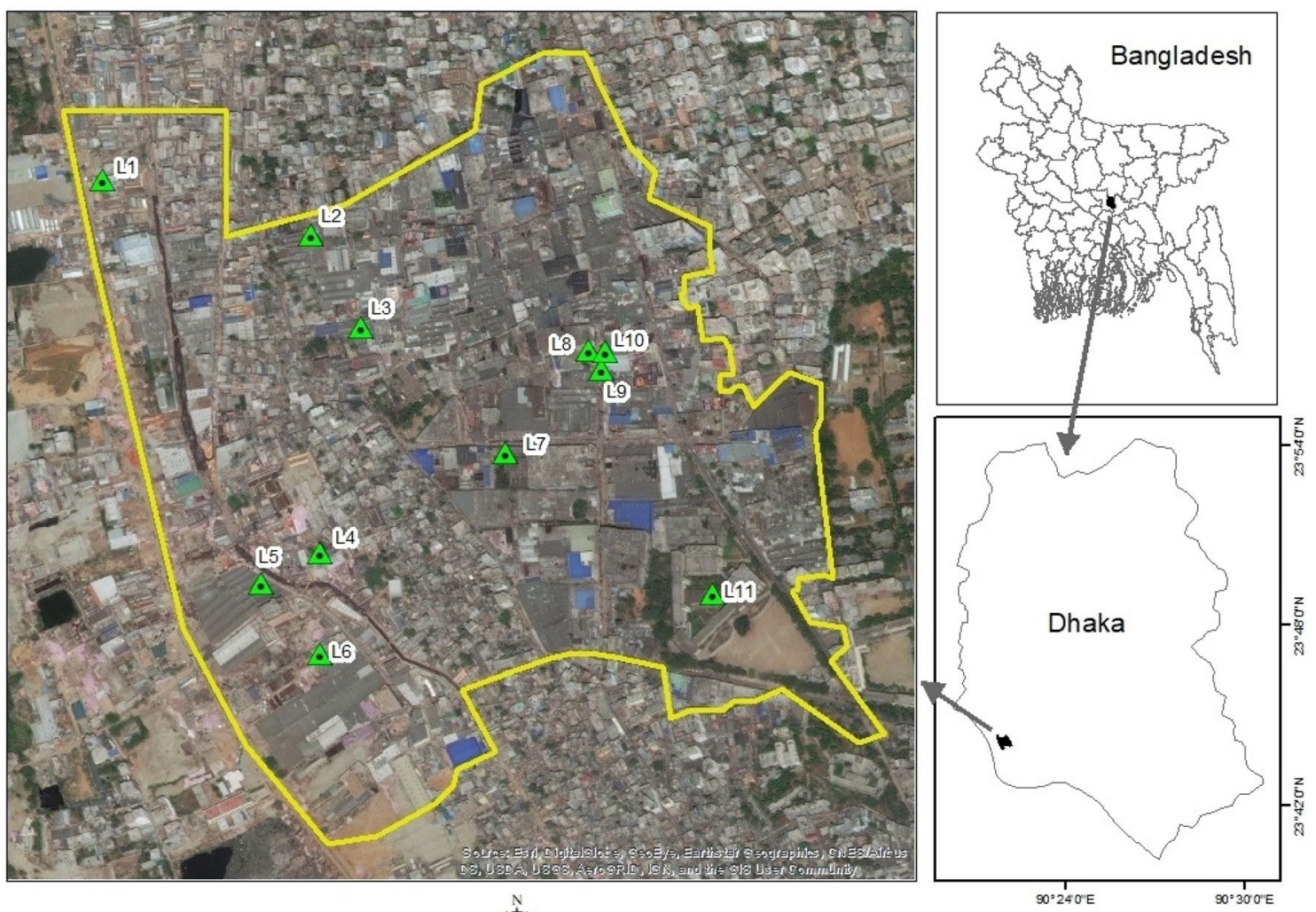

0.25 $0.5 \mathrm{~km}$

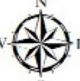

$90^{\circ} 240^{\circ} \mathrm{E}$

$20^{\circ} 30^{\circ}$

Fig. 1 Map of the study area and soil sampling locations

Table 1 Coordinates of the soil and plant sampling locations

\begin{tabular}{llll}
\hline Sample site & Geographical location & Soil & Vegetable \\
\hline L1 & $23^{\circ} 44^{\prime} 16.0^{\prime \prime} \mathrm{N} 90^{\circ} 21^{\prime} 41.8^{\prime \prime} \mathrm{E}$ & $\sqrt{ }$ & $\times$ \\
L2 & $23^{\circ} 44^{\prime} 13.8^{\prime \prime} \mathrm{N} 90^{\circ} 21^{\prime} 50.7^{\prime \prime} \mathrm{E}$ & $\sqrt{ }$ & $\times$ \\
L3 & $23^{\circ} 44^{\prime} 10.2^{\prime \prime} \mathrm{N} 90^{\circ} 21^{\prime} 52.9^{\prime \prime} \mathrm{E}$ & $\sqrt{ }$ & $\times$ \\
L4 & $23^{\circ} 44^{\prime} 01.3^{\prime \prime} \mathrm{N} 90^{\circ} 21^{\prime} 51.1^{\prime \prime} \mathrm{E}$ & $\sqrt{ }$ & $\sqrt{ }$ \\
L5 & $23^{\circ} 44^{\prime} 00.1^{\prime \prime} \mathrm{N} 90^{\circ} 21^{\prime} 48.6^{\prime \prime} \mathrm{E}$ & $\sqrt{ }$ & $\times$ \\
L6 & $23^{\circ} 43^{\prime} 57.3^{\prime \prime} \mathrm{N} 90^{\circ} 21^{\prime} 51.1^{\prime \prime} \mathrm{E}$ & $\sqrt{ }$ & $\times$ \\
L7 & $23^{\circ} 44^{\prime} 05.2^{\prime \prime} \mathrm{N} 90^{\circ} 21^{\prime} 59.1^{\prime \prime} \mathrm{E}$ & $\sqrt{ }$ & $\sqrt{ }$ \\
L8 & $23^{\circ} 44^{\prime} 09.3^{\prime \prime} \mathrm{N} 90^{\circ} 22^{\prime} 02.6^{\prime \prime} \mathrm{E}$ & $\sqrt{ }$ & $\times$ \\
L9 & $23^{\circ} 44^{\prime} 08.5^{\prime \prime} \mathrm{N} 90^{\circ} 22^{\prime} 03.2^{\prime \prime} \mathrm{E}$ & $\sqrt{ }$ & $\times$ \\
L10 & $23^{\circ} 44^{\prime} 09.2^{\prime \prime} \mathrm{N} 90^{\circ} 22^{\prime} 03.4^{\prime \prime} \mathrm{E}$ & $\sqrt{ }$ & $\sqrt{ }$ \\
L11 & $23^{\circ} 43^{\prime} 59.7^{\prime \prime} \mathrm{N} 90^{\circ} 22^{\prime} 08.0^{\prime \prime} \mathrm{E}$ & $\sqrt{ }$ & $\times$ \\
\hline
\end{tabular}

\subsection{Digestion of soil samples}

Soil samples were digested following ISO 11466 Standard Method [26] with slight modification [27]. Soil material was oven-dried and lightly ground in an agate mortar and pestle. Five grams soil was transferred to a beaker and $10 \mathrm{~mL}$ of $65 \%(\mathrm{w} / \mathrm{v}) \mathrm{HNO}_{3}$ and $37 \%(\mathrm{w} / \mathrm{v}) \mathrm{HCl}$ in a $1: 3$ ratio was added and kept overnight. The sample was refluxed for $2 \mathrm{~h}$, diluted in distilled water to $500 \mathrm{ml}$, and filtered through $0.45 \mu \mathrm{m}$ filter paper. The filtrate was collected in clean plastic bottles for heavy metal $(\mathrm{Cr}, \mathrm{Pb}, \mathrm{Cu}, \mathrm{Zn}, \mathrm{Ni}$, and $\mathrm{Cd}$ ) determination using direct air/acetylene mixture by flame atomic absorption spectrophotometry (FAAS). A linear calibration was performed with standard solutions before each analysis in an Atomic Absorption Spectrophotometer (Shimadzu AA6800). All elemental analysis via FAAS was performed following Standard Method 3111 [28]. The minimum detection limit of the instrument was $0.001 \mathrm{mg} / \mathrm{L}$ for $\mathrm{Cr}, \mathrm{Cu}, \mathrm{Zn}$, and $\mathrm{Cd}$ and $0.01 \mathrm{mg} / \mathrm{L}$ for $\mathrm{Pb}$ and $\mathrm{Ni}$. The mean and standard deviation of three replicates for each sampling location is reported in this study. Analyzed heavy metal concentrations were compared with China and Finland maximum permissible limits.

\subsection{Digestion of plant samples}

Plant samples were digested following Standard Method 3030 [29]. Washed spinach plants (edible parts only) were oven-dried at $105^{\circ} \mathrm{C}$ in an aluminum bowl. Two $\mathrm{g}$ of dried pulverized plant tissue was placed in a flask followed by 
addition of $2-3 \mathrm{~mL}$ distilled water, and $25 \mathrm{~mL}$ of $65 \%(\mathrm{w} / \mathrm{v})$ $\mathrm{HNO}_{3}$, and the mixture was stored for $24 \mathrm{~h}$. The flask was subsequently heated to boiling for $2 \mathrm{~h}$. After cooling, $10 \mathrm{~mL}$ of $70 \%(\mathrm{w} / \mathrm{v})$ perchloric acid was added to the flask and heated again to boiling for $1 \mathrm{~h}$. The digestion was considered complete when the color of the solution turned yellow. If the solution remained dark in color, then $2-3 \mathrm{~mL}$ of $65 \%(\mathrm{w} / \mathrm{v}) \mathrm{HNO}_{3}$ was added and heat was re-applied. The process was repeated until the yellow color appeared. The digested solution was filtered through a $0.45 \mu \mathrm{m}$ filter and collected in plastic bottles for determination of $\mathrm{Cr}, \mathrm{Pb}$, $\mathrm{Cu}, \mathrm{Zn}, \mathrm{Ni}$, and $\mathrm{Cd}$ by FAAS following Standard Method $3111[28]$.

\subsection{Leaching test}

For evaluating the risks from leaching of heavy metals, the Toxicity Characteristics Leaching Procedure (TCLP) was used in accordance with USEPA Method 1311 [30]. Dried and pulverized soil samples which passed through a $9.5 \mathrm{~mm}$ mesh standard sieve were placed into a glass cylinder. An acetic acid solution $(0.57 \% \mathrm{v} / \mathrm{v})$ was added to the samples in a 20:1 ratio. The $\mathrm{pH}$ of the extraction fluid was adjusted to $2.88 \pm 0.05$. After rotating the cylinder for $18 \mathrm{~h}$ at $30 \pm 2 \mathrm{rpm}$, the leachate was filtered through a $0.45 \mu \mathrm{m}$ filter, and $\mathrm{HNO}_{3}$ added to maintain filtrate $\mathrm{pH}$ at less than 2. The extracts were analyzed for $\mathrm{Cr}, \mathrm{Pb}, \mathrm{Zn}, \mathrm{Cu}$, and $\mathrm{Ni}$ by FAAS (Shimadzu AA 6800).

\subsection{Data analysis}

Heavy metal spatial distribution maps were generated using ArcGIS 10.6. $1^{\mathrm{TM}}$ employing an Inverse Distance Weighted (IDW) interpolation method. Pairwise correlation of heavy metal concentrations was performed using Microsoft Excel.

\subsection{Factors for ecological risk analysis}

Contamination factor $\left(C F^{i}\right)$ : The estimate of heavy metal contamination and enrichment of metal in soil was assessed by the contamination factor $\left(C F^{j}\right)$, denoted as:

$C F^{i}=\frac{C^{i}}{B^{i}}$

where $C^{i}$ is the metal concentration of the soil sample and $B^{i}$ is the standard background concentration of the $i$-th element. In this study, the standard background value was derived from the average of three different, widely accepted background values: (1) the average concentration in shale; (2) the average crustal content of the earth; and (3) the worldwide mean concentration of the metal in soil [3, 31, 32]. Four categories express the contamination factor: $C F^{i}<1$ indicates a low contamination factor, i.e., low soil contamination; $1 \leq C F^{i}<3$ is moderate contamination; $3 \leq C F^{i}<6$ is considerable contamination; and $6 \leq C F^{i}$ stands for very high contamination $[33,34]$.

Degree of contamination $\left(C_{\text {deg }}\right)$ : This value assesses the concentration of multi-metal contamination in soil, where the contamination factor accounts for the concentration of a single metal $[3,33]$. The value embraces the total metal contamination at a sampling point. The equation is:

$C_{\mathrm{deg}}=\sum_{i=1}^{\infty} C F^{i}$

where $C F^{i}$ is the contamination factor of the metal in the study area. According to Hakanson [33], $C_{d e g}<8$ represents a low degree of contamination; $8 \leq C_{d e g}<16$ represents moderate contamination; $16 \leq C_{\text {deg }}<32$ represents considerable contamination; and $32 \leq C_{\text {deg }}$ represents a very high degree of contamination.

Pollution load index (PLI): The PLI, proposed by Tomlinson [35], is used to assess the extent of pollutants (heavy metals in this case) of a particular location [3]. PLI is calculated by obtaining the $n$-th root of the product of CFs obtained for $n$ number of metals as follows:

$P L I=\sqrt[n]{C F^{1} \times C F^{2} \times C F^{3} \times \cdots \times C F^{n}}$

A site is designated as polluted when the $P L /$ value $>1$.

Geoaccumulation index $\left(l_{\text {geo }}\right)$ : The index of geoaccumulation, first proposed by Muller [36] is used to assess the degree of soil contamination of the selected area; it compares the measured heavy metal content against the background concentrations of that element:

$I_{\text {geo }}=\log _{2}\left[\frac{C^{n}}{1.5 \times B^{n}}\right]$

where $C^{n}$ is the measured metal concentration of the soil sample and $B^{n}$ is the standard background concentration of element $n$. The numerical factor 1.5 is applied to account for possible variations in background values of a metal due to the lithological differences as well as anthropogenic influences. $I_{\text {geo }}$ is classified into seven categories: $I_{\text {geo }} \leq 0$ represents unpolluted; $0<I_{\text {geo }} \leq 1$ slightly polluted; $1<I_{\text {geo }} \leq 2$ moderately polluted; $2<I_{\text {geo }} \leq 3$ moderately to severely polluted; $3<I_{\text {geo }} \leq 4$ severely polluted; $4<I_{\text {geo }} \leq 5$ severely to extremely polluted; and $5<I_{\text {geo }} \leq 6$ extremely polluted $[3,34,36]$.

Ecological risk factor $\left(E r^{i}\right)$ : The ecological risk factor $\left(E r^{\prime}\right)$ is used to determine the ecological risk of an area contaminated with heavy metals [3]. This risk assessment method has been widely used to determine the impact of heavy metal contamination $[37,38]$ and is expressed by: 
$E r^{i}=T^{i} \times C F^{i}$

where $T^{i}$ is the toxic response factor of the metal, and $C F^{i}$ is the contamination factor of the metal. The $T^{i}$ value of $\mathrm{Pb}, \mathrm{Cr}, \mathrm{Zn}, \mathrm{Cu}$, and $\mathrm{Ni}$ are, respectively, 5, 2, 1, 5, and 5, as evaluated by Hakanson [33]. The risk factor has five categories: $E r^{i}<40$ represents a low potential ecological risk; $40 \leq E r^{i}<80$ a moderate potential ecological risk; $80 \leq E r^{i}<160$ a considerable potential ecological risk; $160 \leq E r^{i}<320$ a high potential ecological risk, and $E r^{i} \geq 320$ a very high ecological risk.

Ecological risk index (RI): The $R l$ is the summation of risk factors $\left(E r^{\prime}\right)$ for the location. $R l$ is used to represent the toxicity of the heavy metal and the environmental response of $\mathrm{Cr}, \mathrm{Zn}, \mathrm{Cu}, \mathrm{Pb}$, and $\mathrm{Ni}$ in the study area [34]:

$R I=\sum_{i=1}^{\infty} E r^{i}$

$R I<150$ represents low ecological risk; $150 \leq R I<300$ moderate ecological risk; $300 \leq R I<600$ considerable ecological risk; and $R I \geq 600$ very high ecological risk [34].

Transfer Factor (TF): The transfer factor is used to assess heavy metal uptake by plants. In this study, the transfer factor of five metals was determined from the edible part of plants grown in contaminated soil. The following equation is used to calculate TF [39]:

$T F=\frac{\text { Concentration of metal in edible part }}{\text { Concentration of metal in soil }}$

\subsection{Human exposure and health risk assessment}

Non-carcinogenic health risk assessment method: Human exposure and health risk assessment is a multi-step process that includes determination of chronic daily intake $(C D I)$, Hazard quotient $(H Q)$, Hazard index $(H I)$, Carcinogenic Risk $(C R)$, and risk characterization [40]. In this case, we estimated the exposure due to the intrusion of heavy metal from the soil through various pathways. Heavy metal entry into the human body can occur via oral ingestion $\left(C D I_{\text {ing }}\right)$, absorption through exposed skin $\left(C D I_{\text {dermal }}\right)$, and inhalation $\left(C D I_{i n h}\right)$ [41]. Ingestion of $\mathrm{Pb}, \mathrm{Cr}, \mathrm{Cu}, \mathrm{Cd}$, and $\mathrm{Ni}$ from soil is considered the main human exposure pathway [42]. Both non-carcinogenic and carcinogenic risks were calculated for adult and child residents of the study area. For assessing non-carcinogenic risks of human health (adult and child), Eqs. 8-12 were used [40, 43-45].

$C D I_{\text {ing }}=\frac{C S \times \operatorname{lngR} \times E F \times E D}{B W \times A T} \times C F$
$C D I_{\text {dermal }}=\frac{C S \times S A \times A F \times A B S d \times \operatorname{lngR} \times E F \times E D}{B W \times A T} \times C F$

$C D I_{\text {inh }}=\frac{C S \times \operatorname{lnh} R \times E F \times E D}{B W \times A T} \times C F$

$H Q=\frac{C D I}{R f D}$

$H I=\sum H Q=H Q_{i n g}+H Q_{\text {dermal }}+H Q_{i n h}$

$$
=\frac{C D I_{\text {ing }}}{R f D_{\text {ing }}}+\frac{C D I_{\text {dermal }}}{R f D_{\text {dermal }}}+\frac{C D I_{\text {inh }}}{R f D_{\text {inh }}}
$$

where, CS represents heavy metal concentration in soil. The other parameters, units, and standard values used for evaluating non-carcinogenic risks appear in Table 2. Calculation of $H Q$ was performed by dividing the $C D I$ with the corresponding reference doses $(R f D)$ of different metals ( $\mathrm{Pb}, \mathrm{Cr}$ and $\mathrm{Cu}$ ) (Table 2). A value of $\mathrm{HQ}$ lower than 1 indicates no significant human health risk, and $H Q$ greater than 1 indicates a potentially serious health risk. Cumulative non-cancer hazard $H I$ was calculated by summing the $H Q$ of ingestion, dermal, and inhalation. When the value of $H \mathrm{H}$ exceeds unity it indicates an extreme health risk. Increasing trends of $H I$ raise the probability of noncarcinogenic risks accordingly [46].

Carcinogenic risk analysis for adults and children: Determination of carcinogenic risk to humans was calculated by Eqs. 13-16 [40, 43-45]:

$C R_{\text {ing }}=\frac{C S \times A F \times \operatorname{lng} R \times E F \times E D \times C F \times C S F_{i n g}}{B W \times A T}$

$C R_{\text {dermal }}=\frac{C S \times S A \times A F \times A B S_{d} \times E F \times E D \times C F \times C S F_{i n g} \times A B S_{G I}}{B W \times A T}$

$C R_{i n h}=\frac{C S \times E T \times E F \times E D \times I U R}{P E F \times 24 \times A T} \times 10^{3}$

Total carcinogenic risk $\left(C R_{\text {total }}\right)=\sum$ Risk $=C R_{\text {ing }}+C R_{\text {dermal }}+C R_{\text {inh }}$

where $C R_{\text {ing }}, C R_{\text {dermal }}$ and $C R_{\text {inh }}$ represent cancer risk via ingestion, dermal contact and inhalation from soil, successively. The total cancer risk ( $\left.C R_{\text {total }}\right)$ posed by heavy metals, as indicated by Eq. 16, is the summation of risks posed by the three pathways. Opinions are divided as to what constitutes 'acceptable risk' for carcinogenic effects. A cancer risk $\left(C R_{\text {total }}\right)$ lower than $1 \times 10^{-6}(1$ in $10,00,000$ probability of developing cancer) indicates negligible risk, and $C R_{\text {total }}$ greater than $10^{-6}$ is considered unacceptable by many international health regulatory bodies $[41,43]$. Other 
Table 2 Parameters for human exposure and health risk assessment of contaminated soil of former tannery areas

\begin{tabular}{|c|c|c|c|c|}
\hline \multirow[t]{2}{*}{ Parameters } & \multirow[t]{2}{*}{ Units } & \multicolumn{2}{|l|}{ Value (Resident) } & \multirow[t]{2}{*}{ References } \\
\hline & & Adult & Child & \\
\hline Ingestion rate (IngR) & $\mathrm{mg} \mathrm{d}^{-1}$ & 100 & 200 & {$[40]$} \\
\hline Exposure frequency (EF) & $\mathrm{d} \mathrm{yr}^{-1}$ & 350 & 350 & {$[40]$} \\
\hline Exposure duration (ED) & $\mathrm{Yr}$ & 30 & 6 & {$[40]$} \\
\hline Average body weight (BW) & $\mathrm{Kg}$ & 70 & 15 & [49] \\
\hline Average time $(A T=365 x E D)$ & $\mathrm{Yr}$ & 10950 & 2190 & {$[40]$} \\
\hline Conversion factor (CF) & $\mathrm{kg} \mathrm{mg}^{-1}$ & $10^{-6}$ & $10^{-6}$ & {$[50]$} \\
\hline Exposure skin area (SA) & $\mathrm{cm}^{2}$ & 5700 & 1600 & [49] \\
\hline Adherence factor (AF) & $\mathrm{mg} \mathrm{cm}^{-2}$ & 0.07 & 0.2 & {$[40]$} \\
\hline Dermal absorption factor $\left(\mathrm{ABS}_{\mathrm{d}}\right)$ & Unitless & \multicolumn{2}{|c|}{$\begin{array}{l}0.001 \text { for all metals except } \\
\text { As }\end{array}$} & [49] \\
\hline Inhalation rate (InhR) & $m^{3} d^{-1}$ & \multicolumn{2}{|l|}{20} & {$[44]$} \\
\hline Chronic oral slope factor $\left(\mathrm{CSF}_{\text {ing }}\right)$ & $\left(m g g^{-1} d^{-1}\right)^{-1}$ & \multicolumn{2}{|l|}{$\begin{array}{l}\mathrm{Pb}=0.0085 \\
\mathrm{Cr}=4.1\end{array}$} & {$[40]$} \\
\hline Gastrointestinal absorption factor $\left(\mathrm{ABS}_{\mathrm{GI}}\right)$ & Unitless & \multicolumn{2}{|l|}{$\begin{array}{l}\mathrm{Pb}=1 \\
\mathrm{Cr}=0.013\end{array}$} & [49] \\
\hline Particle emission factor (PEF) soil to air & $\mathrm{m}^{3} \mathrm{~kg}^{-1}$ & \multicolumn{2}{|l|}{$1.36 \times 10^{9}$} & {$[40],[49]$} \\
\hline Chronic inhalation unit risk (IUR) & $\left(\mu \mathrm{g} \mathrm{m}^{-3}\right)^{-1}$ & \multicolumn{2}{|l|}{$\begin{array}{l}\mathrm{Pb}=0.000012 \\
\mathrm{Cr}=0.012\end{array}$} & {$[40]$} \\
\hline Exposure time (ET) & $h d^{-1}$ & \multicolumn{2}{|l|}{24} & {$[40]$} \\
\hline $\begin{array}{l}\text { Reference dose (RfD) for ingestion, inhala- } \\
\text { tion and dermal }\end{array}$ & $\mathrm{mg} \mathrm{kg}^{-1} \mathrm{~d}^{-1}$ & \multicolumn{2}{|l|}{$\begin{array}{l}\mathrm{Cr}=0.003 \\
\mathrm{~Pb}=0.0035 \\
\mathrm{Cu}=0.04\end{array}$} & {$[40],[50]$} \\
\hline
\end{tabular}

studies have indicated the range $1 \times 10^{-6}<\mathrm{CR} \leq 1 \times 10^{-4}$ to be an acceptable level for carcinogenic risk $[47,48]$ though $C R_{\text {total }}=10^{-6}$ is considered unacceptable by USEPA [49]. For risk assessment of heavy metal contamination in Hazaribagh soil, we assumed a less conservative threshold - we considered $C R_{\text {total }}<1 \times 10^{-4}$ to be an acceptable level of risk.

\section{Results and Discussion}

\subsection{Soil properties}

Soil pH averaged 7.6 (range 6.9-8.3) (Table 3). The alkaline $\mathrm{pH}$ of the topsoil may be a consequence of the disposal of spent lime liquor used in the liming operations of leather processing. The high $\mathrm{pH}$ of sites L5-L10 is likely the result of dumping of limed fleshing (a portion of hides and skins containing lime solution separated after fleshing operation) in these areas for storage and final disposal. Other studies have shown similar pH values in Hazaribagh soil $[15,25]$. The organic matter content varied from 3 to $12 \%$. Solid waste containing organic matter from leather industries and untreated tannery effluents is the probable source of this high-soil organic content.

\subsection{Spatial distribution of heavy metals}

The relative abundance and spatial distribution of $\mathrm{Pb}, \mathrm{Cr}$, $\mathrm{Zn}, \mathrm{Cu}, \mathrm{Ni}$, and $\mathrm{Cd}$ in Hazaribagh are shown in Table 3 and Fig. 2. We compared heavy metal concentrations with the soil contaminant thresholds of Finland and China [51, 52]. The Ministry of Environment (MoE) of Finland recommends contaminant remediation when one or more harmful substances in the soil exceeds the threshold concentration. All sites except L5, L8, and L11, were contaminated with high concentrations of chromium ranging from 294 to $23,148 \mathrm{mg} / \mathrm{kg}$, which exceeded the maximum permissible concentration (MPC) for both Finland (100 mg/ $\mathrm{kg}$ ) and China (200 mg/kg). The average $\mathrm{Cr}$ concentration in the study area was $4321 \mathrm{mg} / \mathrm{kg}$ (Table 3), which is approximately 22- and 43-fold higher than the restriction limit set by China and Finland, respectively. Location L1 $(23,148 \mathrm{mg} / \mathrm{kg})$ and $\mathrm{L} 6(12682 \mathrm{mg} / \mathrm{kg})$ are the most contaminated with respect to $\mathrm{Cr}$ among all other locations. This may be due to the use of these areas as dumping grounds for chrome shaving scraps, trimmings and buffing dust. Additionally, the canal that flowed beside these sites and carried untreated effluent overflowed frequently during periods of heavy rain when production was at full capacity. Sites L2, L7, and L10 also had significantly highCr concentrations $(2440-2900 \mathrm{mg} / \mathrm{kg}$ ) due to proximity to effluent discharge points. L1, L2, and L6 were previously 
Table $3 \mathrm{pH}$, organic content (OC) (\%) and heavy metal concentrations ( $\mathrm{mg} / \mathrm{kg})$ of soils in Hazaribagh

\begin{tabular}{lllllllll}
\hline Sample & $\mathrm{pH}$ & $\mathrm{OC}$ & $\mathrm{Pb}$ & $\mathrm{Cr}$ & $\mathrm{Zn}$ & $\mathrm{Cu}$ & $\mathrm{Ni}$ \\
\hline L1 & 7.4 & 11.5 & $52.4 \pm 1.1$ & $23,148 \pm 48.6$ & $558.9 \pm 2.75$ & $66.3 \pm 0.2$ & $4.05 \pm 0.07$ & $\mathrm{Cd}$ \\
L2 & 7.0 & 7.3 & $59.6 \pm 1.1$ & $2438.9 \pm 10.8$ & $193.7 \pm 1.13$ & $271.8 \pm 0.28$ & $19.9 \pm 0.42$ & $\mathrm{n} . \mathrm{d}$ \\
L3 & 7.7 & 12 & $70.6 \pm 1.1$ & $1458 \pm 3.67$ & $250.9 \pm 1.34$ & $115 \pm 0.28$ & $8.65 \pm 0.21$ & $\mathrm{n} . \mathrm{d}$ \\
L4 & 7.5 & 10.7 & $61.25 \pm 1.2$ & $1834.8 \pm 3.67$ & $304 \pm 1.2$ & $58.25 \pm 7.40$ & $8.45 \pm 0.49$ & $\mathrm{n} . \mathrm{d}$ \\
L5 & 7.8 & 11 & $61.5 \pm 0.1$ & $34.85 \pm 2.19$ & $327.1 \pm 2.67$ & $323.2 \pm 0.56$ & $9 \pm 0.56$ & $\mathrm{n} . \mathrm{d}$ \\
L6 & 8.2 & 9.5 & $23.95 \pm 0.77$ & $12,682 \pm 51.56$ & $53.75 \pm 1.76$ & $35.9 \pm 0.14$ & $3 \pm 0.42$ & n.d \\
L7 & 7.9 & 11.4 & $130 \pm 0.77$ & $2492.6 \pm 10.8$ & $1034 \pm 14.56$ & $301 \pm 0.07$ & $12.25 \pm 0.21$ & n.d \\
L8 & 8.3 & 7.8 & $16.75 \pm 0.77$ & $115.8 \pm 5.25$ & $77.8 \pm 2.26$ & $32.5 \pm 0.28$ & $6.6 \pm 0.14$ & n.d \\
L9 & 7.8 & 6.7 & $15.7 \pm 1.5$ & $294.6 \pm 10.88$ & $20 \pm 1.2$ & $30 \pm 0.12$ & $5.55 \pm 0.07$ & n.d \\
L10 & 6.9 & 8.6 & $62.9 \pm 0.42$ & $2888.9 \pm 0.2$ & $210.35 \pm 0.77$ & $75.5 \pm 0.42$ & $9.85 \pm 0.35$ & n.d \\
L11 & 7.1 & 3.1 & $41.9 \pm 0.42$ & $145.45 \pm 7.28$ & $127.5 \pm 32.4$ & $133.05 \pm 2.1$ & $9.25 \pm 0.92$ & n.d \\
Mean & 7.6 & 9.1 & 54 & 4321 & 287 & 131 & 9 & - \\
Background value [3] & - & - & $19.66 \pm 5.50$ & $90.66 \pm 44.73$ & $75.66 \pm 17.21$ & $38 \pm 21.3$ & $35.33 \pm 28.30$ & $1.56 \pm 1.35$ \\
China limit [51] & - & - & 120 & 200 & 250 & 100 & 100 & 0.3 \\
MoE, Finland [52] & - & - & 60 & 100 & 200 & 100 & 50 & 1 \\
\hline
\end{tabular}

n.d: not detected; detection limit of $\mathrm{Cd}$ is $>0.001 \mathrm{mg} / \mathrm{l}$

storage locations for $\mathrm{Cr}$-rich solid wastes, which were used to make glue and gelatine. Previous studies found similar levels of $\mathrm{Cr}(1000-30,000 \mathrm{mg} / \mathrm{kg})$ in soil near discharge canals and solid waste disposal sites and indicated the possibility of $\mathrm{Cr}$ leaching to groundwater [11, 15, 25, 53]. Almost all $\mathrm{Cr}$ accumulated in the soils occurred as $\mathrm{Cr}(\mathrm{III})$ [54], and only insignificant quantities of $\mathrm{Cr}$ were available as $\mathrm{Cr}(\mathrm{VI})$ [25]. The soil of the Hazaribagh area had insignificant quantities of $\mathrm{MnO}(0.1-0.08 \%)$ which does not change appreciably with depth [25]. This indicates that catalytic oxidation of $\mathrm{Cr}(\mathrm{III})$ to $\mathrm{Cr}(\mathrm{VI})$ by $\mathrm{MnO}$ may not be occurring, and $\mathrm{Cr}$ (III) remains the dominant form of $\mathrm{Cr}$.

Soil $\mathrm{Cu}$ concentrations were highest in locations L2, L3, L5, L7, and L11, exceeding both Finland and China regulatory limits of $100 \mathrm{mg} / \mathrm{kg}$ (Fig. 2). Additionally, $\mathrm{Cu}$ concentrations in all the sites except L6, L8, and L9 were higher than background values. Soil $\mathrm{Zn}$ distribution is similar to those of Cu; locations L1 (559 mg/kg), L3 (251 mg/ $\mathrm{kg}$ ), L4 (304 mg/kg), L5 (327 mg/kg), and L7 (1034 mg/kg) exceeded the Finland and China standards (Table 3 ). Soil $\mathrm{Pb}$ concentration ranged from 16 to $130 \mathrm{mg} / \mathrm{kg}$ with a mean of $54 \mathrm{mg} / \mathrm{kg}$ (Table 3). Soil L3 (71 mg/kg), L4 (61 mg/ $\mathrm{kg})$, L5 (62 mg/kg), L7 (130 mg/kg), and L10 (63 mg/kg) exceeded the Finland standard. Except for $L 7(130 \mathrm{mg} / \mathrm{kg})$ all concentrations were below the MPC of China, though significantly higher than the standard background value. Similar concentration ranges of $\mathrm{Pb}$ have been determined in previous studies [25]. The impact of $\mathrm{Ni}$ and $\mathrm{Cd}$ is considered negligible as their concentrations were far below the international benchmark for background values. Spatial variation of heavy metals in soil of tannery industrial areas was reported by researchers in India [55], Pakistan [5], and Italy [56]. Heavy metal concentration several orders of magnitude over established background levels as well as high spatial variation indicate the consequences of anthropogenic activities modulating the local environment. In the Hazaribagh former tannery area, there were localized discharges of heavy metal-containing wastes, both continuous and sporadic. Therefore, in addition to the overall high-concentration heavy metals, hotspots having high concentrations of $\mathrm{Cr}, \mathrm{Pb}, \mathrm{Cu}$, and $\mathrm{Zn}$ were found (Fig. 2).

\subsection{Correlation among heavy metals}

A significant positive correlation was detected among soil Pd, Zn, Cu, and Ni (Table 4). Cadmium was excluded from analysis as concentrations were below detection levels. Chromium was negatively correlated with all metals except $\mathrm{Zn}$, which may imply that $\mathrm{Cr}$ and the other metals $(\mathrm{Pb}, \mathrm{Cu}$, and $\mathrm{Ni}$ ) may not originate from the same source. This supports the suggestion that the abundance of $\mathrm{Cr}$ in soil is due to specific anthropogenic activities such as chrome tanning and re-tanning operations during leather processing. Sources of soil $\mathrm{Pb}, \mathrm{Zn}, \mathrm{Cu}$, and $\mathrm{Ni}$ are primarily anthropogenic activities (battery disposal, alloy making) other than the tanning operations, though $\mathrm{Pb}$ and $\mathrm{Zn}$ can arise from pigments used in tanning [15]. In addition, salts of $\mathrm{Cu}$ and $\mathrm{Ni}$ are used for dye mordanting (a process where metal salt form metal complexes in dye molecule to act as a link between leather and dye thus modifying the final color of the dye) and thereby used in leather dyeing when the desired color is expected [57]. This practice is currently 

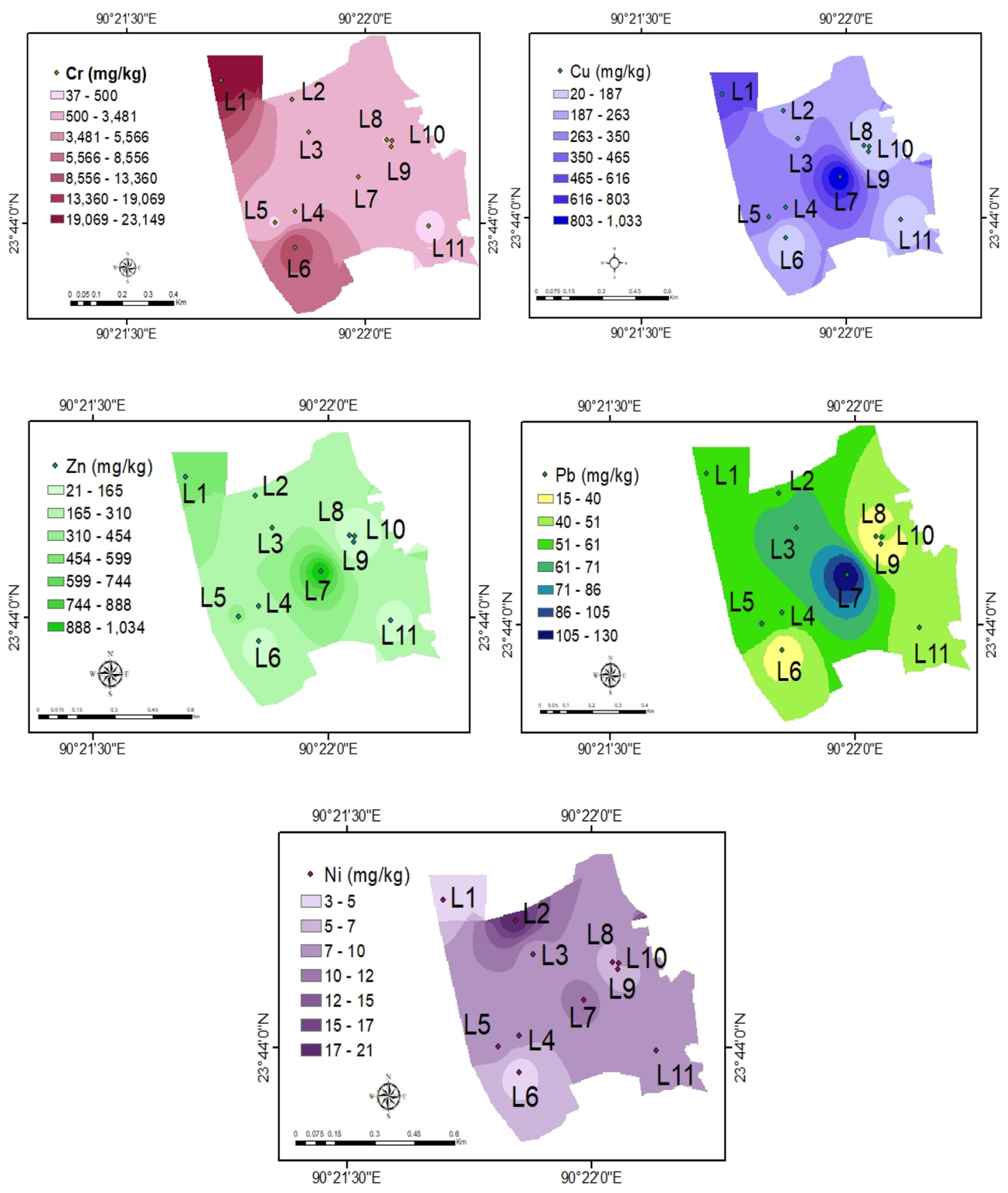

Fig. 2 Spatial distribution of $\mathrm{Cr}, \mathrm{Cu}, \mathrm{Zn}, \mathrm{Pb}$, and $\mathrm{Ni}$ in the soil of Hazaribagh

Table 4 Pearson correlation coefficient for heavy metals in soil (Correlation is significant at $p<0.05$ )

\begin{tabular}{lrllll}
\hline & $\mathrm{Pb}$ & $\mathrm{Cr}$ & $\mathrm{Zn}$ & $\mathrm{Cu}$ & $\mathrm{Ni}$ \\
\hline $\mathrm{Pb}$ & 1 & & & & \\
$\mathrm{Cr}$ & -0.078 & 1 & & & \\
$\mathrm{Zn}$ & 0.884 & 0.220 & 1 & & \\
$\mathrm{Cu}$ & 0.676 & -0.283 & 0.539 & 1 & \\
$\mathrm{Ni}$ & 0.490 & -0.444 & 0.210 & 0.692 & 1 \\
\hline
\end{tabular}

applied with lower frequency in tannery industries, leading to negligible $\mathrm{Cu}$ and $\mathrm{Ni}$ contributions from tanneries.

\subsection{Contamination factor}

The contamination factor $\left(C F^{\mathrm{i}}\right)$ values indicate that all sites were enriched in metals (Table 5 ). The CF value of $\mathrm{Cr}$ for locations L1, L2, L3, L4, L6, L7, and L10 exceeded 6 , indicating very high contamination. During leather 
Table 5 Contamination factor $\left(C F^{i}\right)$ and Geoaccumulation index $\left(I_{g e o}\right)$ of metals in soils of Hazaribagh tannery area (values in parentheses indicate $I_{\text {geo }}$ value)

\begin{tabular}{llllll}
\hline Samples & $\mathrm{Pb}$ & $\mathrm{Cr}$ & $\mathrm{Zn}$ & $\mathrm{Cu}$ & $\mathrm{Ni}$ \\
\hline L1 & $2.67(0.83)$ & $255.33^{* *}\left(7.41^{+++}\right)$ & $7.39^{* *}(2.30)$ & $1.74(0.22)$ & $0.11(-3.71)$ \\
L2 & $3.03^{*}(1.02)$ & $26.90^{* *}\left(4.16^{++}\right)$ & $2.56(0.77)$ & $7.15^{* *}(2.25)$ & $0.56(-1.41)$ \\
L3 & $3.59^{*}(1.26)$ & $16.08^{* *}\left(3.42^{+}\right)$ & $3.32^{*}(1.14)$ & $3.03^{*}(1.01)$ & $0.24(-2.62)$ \\
L4 & $3.12^{*}(1.05)$ & $20.24^{* *}\left(3.75^{+}\right)$ & $4.02^{*}(1.42)$ & $1.53(0.03)$ & $0.24(-2.65)$ \\
L5 & $3.13^{*}(1.06)$ & $0.38(-1.96)$ & $4.32^{*}(1.53)$ & $8.51^{* *}(2.50)$ & $0.25(-2.56)$ \\
L6 & $1.22(-0.30)$ & $139.89^{* *}\left(6.54^{+++}\right)$ & $0.71(-1.08)$ & $0.94(-0.67)$ & $0.08(-4.14)$ \\
L7 & $6.61^{* *}(2.14)$ & $27.49^{* *}\left(4.20^{++}\right)$ & $13.67^{* *}\left(3.19^{+}\right)$ & $7.92^{* *}(2.40)$ & $0.35(-2.11)$ \\
L8 & $0.85(-0.82)$ & $1.28(-0.23)$ & $1.03(-0.54)$ & $0.86(-0.81)$ & $0.19(-3.01)$ \\
L9 & $0.80(-0.91)$ & $3.25(1.12)$ & $0.26(-2.50)$ & $0.79(-0.93)$ & $0.16(-3.26)$ \\
L10 & $3.20^{*}(1.09)$ & $31.87^{* *}\left(4.41^{++}\right)$ & $2.78(0.89)$ & $1.99(0.41)$ & $0.28(-2.43)$ \\
L11 & $2.13(0.51)$ & $1.60(0.10)$ & $1.69(0.17)$ & $3.50^{*}(1.22)$ & $0.26(-2.52)$ \\
\hline
\end{tabular}

${ }^{*}$ Considerable contamination $\left(3 \leq C F^{i}<6\right) ;{ }^{*}$ Very high contamination $\left(6 \leq C F^{i}\right)$; ${ }^{+}$Severely polluted $\left(3<I_{\text {geo }} \leq 4\right) ;{ }^{++}$Severely to extremely polluted $\left(4<I_{\text {geo }} \leq 5\right) ;{ }^{+++}$Extremely polluted $\left(5<I_{\text {geo }} \leq 6\right)$ processing, wastewater containing about $40-50 \%$ basic chromium sulfate was discharged in surrounding low-lying areas and lagoons, resulting in $\mathrm{Cr}$ enrichment [15]. Most sampling points show moderate to considerable $\mathrm{Pb}$ contamination, while L7 possesses very high contamination. The $\mathrm{Pb}$ enrichment may originate from small-scale paint or coating factories, workshops, battery recycling and disposal, and glazing of ceramics in the study area [25]. Lead contamination may also occur from the use of pigments in tanning. Five sites have moderate to very high contamination with $\mathrm{Zn}$ and $\mathrm{Cu}$, while the remainder exhibit low to moderate contamination. Zinc may have originated from galvanization of automobiles and use in zinc alloy factories, whereas Cu may have resulted from wire disposal and its use in various machine parts and alloys. None of the study locations were enriched with $\mathrm{Ni}$. The order of heavy metal contamination in the soils is ranked as $\mathrm{Cr}>\mathrm{Zn}>\mathrm{Cu}>\mathrm{Pb}>\mathrm{Ni}$.

\subsection{Pollution load index, degree of contamination and geo-accumulation index}

The degree of contamination $\left(C_{\text {deg }}\right)$ ranged from 4 to 267 (Fig. 3a), indicating low to a very high degree of contamination by metals. Five sampling locations (L1, L2, L6, L7, and L10) exhibited a very high degree of contamination $\left(C_{d e g}>32\right)$. This suggests that soil in these sites pose a risk to local inhabitants and surrounding flora and fauna. The $P L /$ values for all sites except $L 8$ and $L 9$ were greater than 1 (Fig. 3b), indicating that most of the sampling sites in the former tannery estate of Hazaribagh are polluted with heavy metals. Table 5 delineates the geoaccumulation index $\left(I_{g e o}\right)$ of metals for the study area. The value of $I_{g e o}$ for $\mathrm{Cr}$ is greater than 3 for 7 out of 11 sites, indicating severe pollution.

Those sites polluted by $\mathrm{Cr}$ are also affected by $\mathrm{Pb}$ (Table 5), although the level of pollution is less severe than for $\mathrm{Cr}$. Six sites fall into the moderately polluted category for $\mathrm{Pb}\left(I_{\text {geo }}=1.02-2.14\right)$. Five sites are designated as moderately to severely polluted for $\mathrm{Zn}\left(I_{\text {geo }}=1.14-3.19\right)$. The level of contamination for $\mathrm{Cu}$ is found to be somewhat lower $\left(I_{\text {geo }}=1.01-2.50\right)$. The $I_{\text {geo }}$ value obtained for $\mathrm{Ni}$ is less than 0 , which implies that it imparts no significant health hazard. Based on $I_{\text {geo }}$ values, the major contaminants in Hazaribagh soil are arranged in the order: $\mathrm{Cr}>\mathrm{Zn}>\mathrm{Cu}>\mathrm{Pb}>\mathrm{Ni}$. A similar order of contaminants was observed by Karim et al. [15].

\subsection{Ecological risk factor and risk index}

Average and maximum ecological risk ( $E r)$ values for $\mathrm{Pb}, \mathrm{Zn}$, and $\mathrm{Ni}$ were under 40 (Eq. 5), indicating low potential ecological risk for all sites. The maximum Er value for $\mathrm{Cu}$ exceeded 40 , indicating a moderate risk. On the other hand, the average $\mathrm{Er}$ of $\mathrm{Cr}$ was more than 95 , which denotes considerable risk for the study area. More than half the sites of the eleven sampling locations exhibited low to very high ecological risk posed by $\mathrm{Cr}$ (maximum $\mathrm{Er}$ of $\mathrm{Cr}$ is 511). The higher ecological risk from $\mathrm{Cr}$ is due to its elevated concentration in soil.

The ecological risk index $(R l)$ for most sites was below 150, which indicates low ecological risk (Fig. 4). Location L6 has a moderate risk $(R I=292)$ and $L 1$ possesses considerable risk $(R I=541)$, indicating a potentially toxic environment for residents. The main contributors to the high $\mathrm{Rl}$ are $\mathrm{Cr}$ and $\mathrm{Cu}$ as indicated by $\mathrm{Er}$ values. The risk posed by heavy metals in Hazaribagh soil, as shown by $R I$, is of concern for the area. This is because the city authority is planning for residences, hospitals, educational institutions, and recreational facilities in the area. The current residents also live near the old establishments. Therefore, exposure 
Fig. 3 Degree of contamination a and pollution load index b of 11 sampling sites in the Hazaribagh tannery area

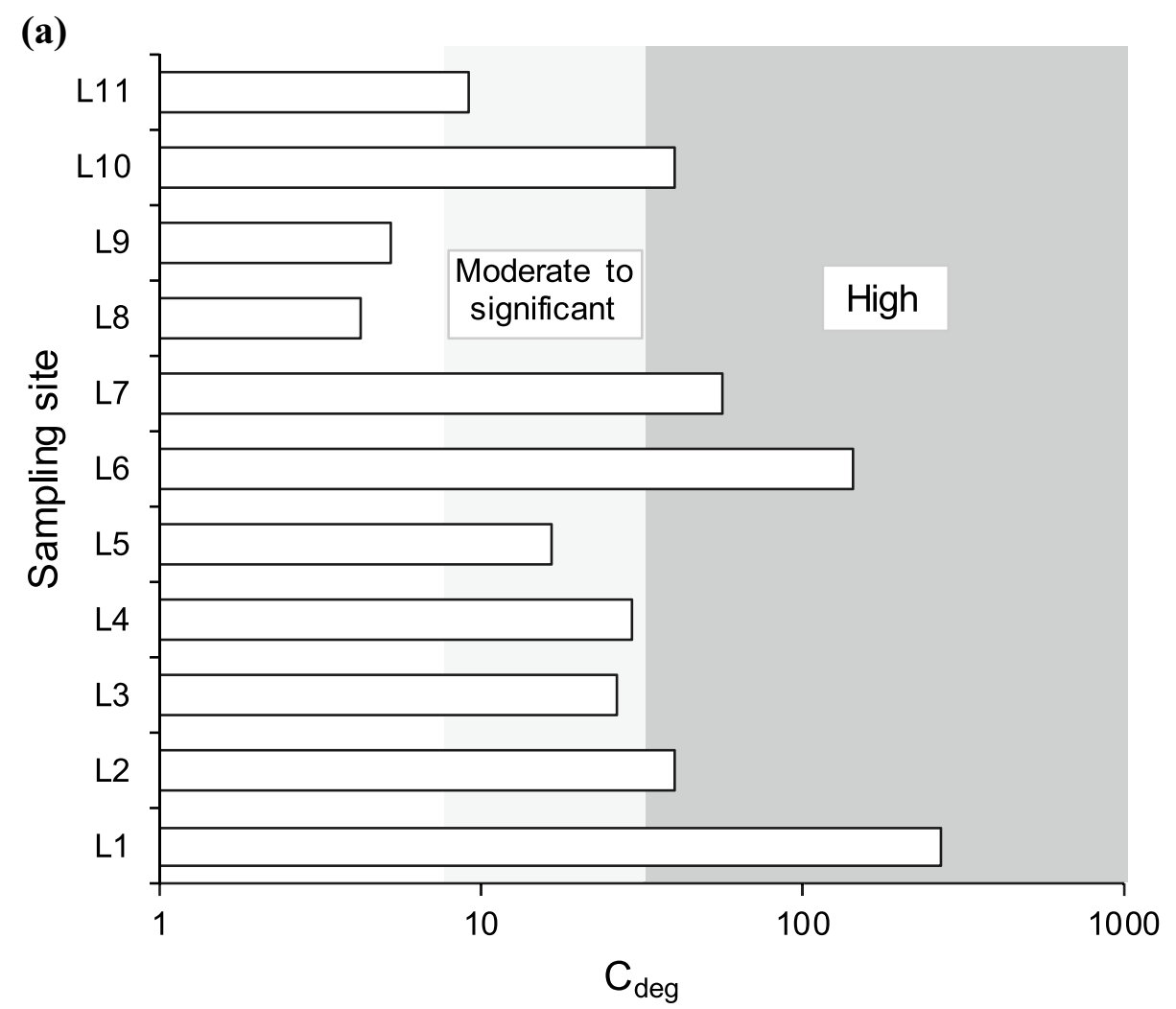

(b)

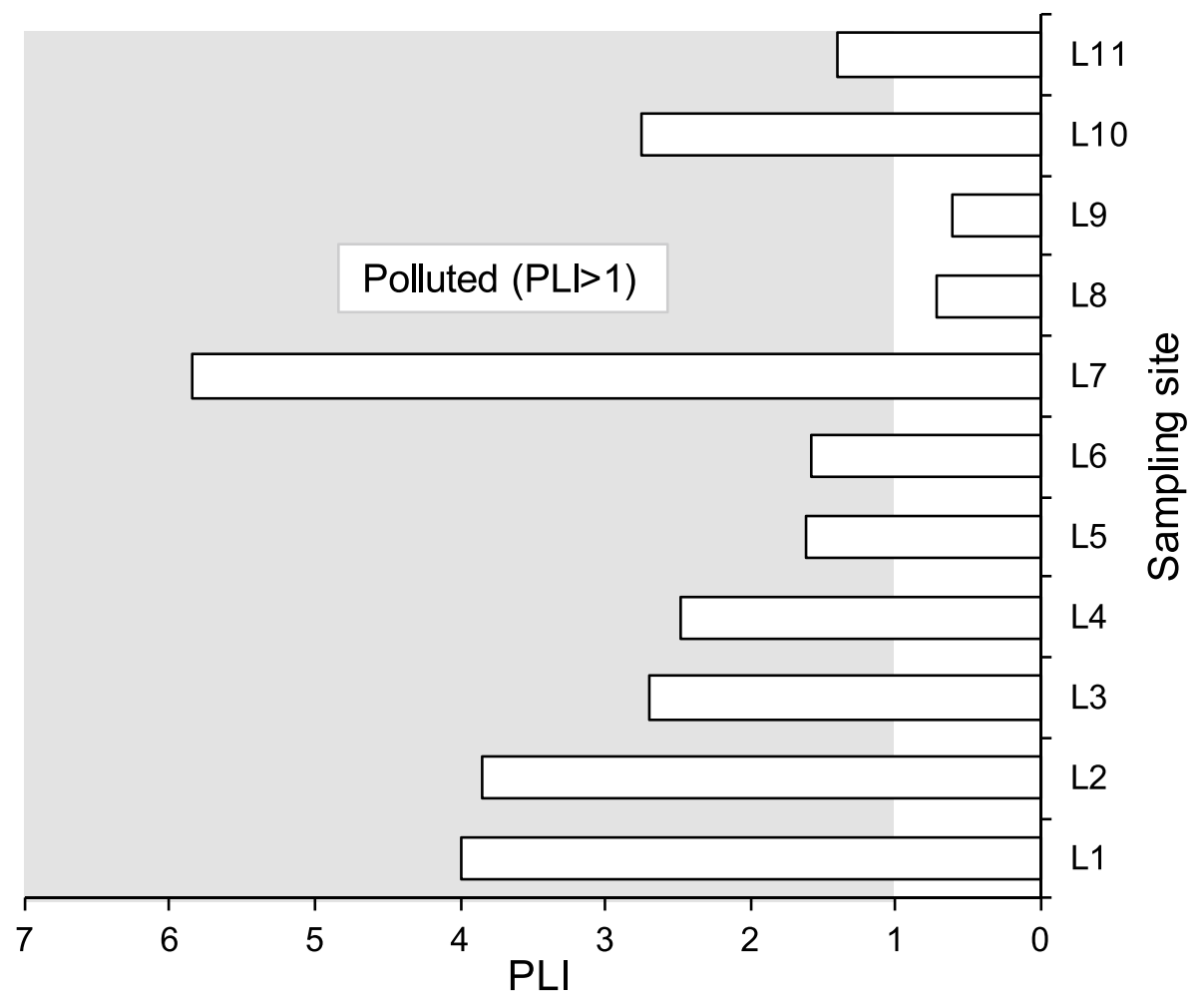


Fig. 4 Ecological risk index $(R I)$ of heavy metals in soil of the Hazaribagh tannery area

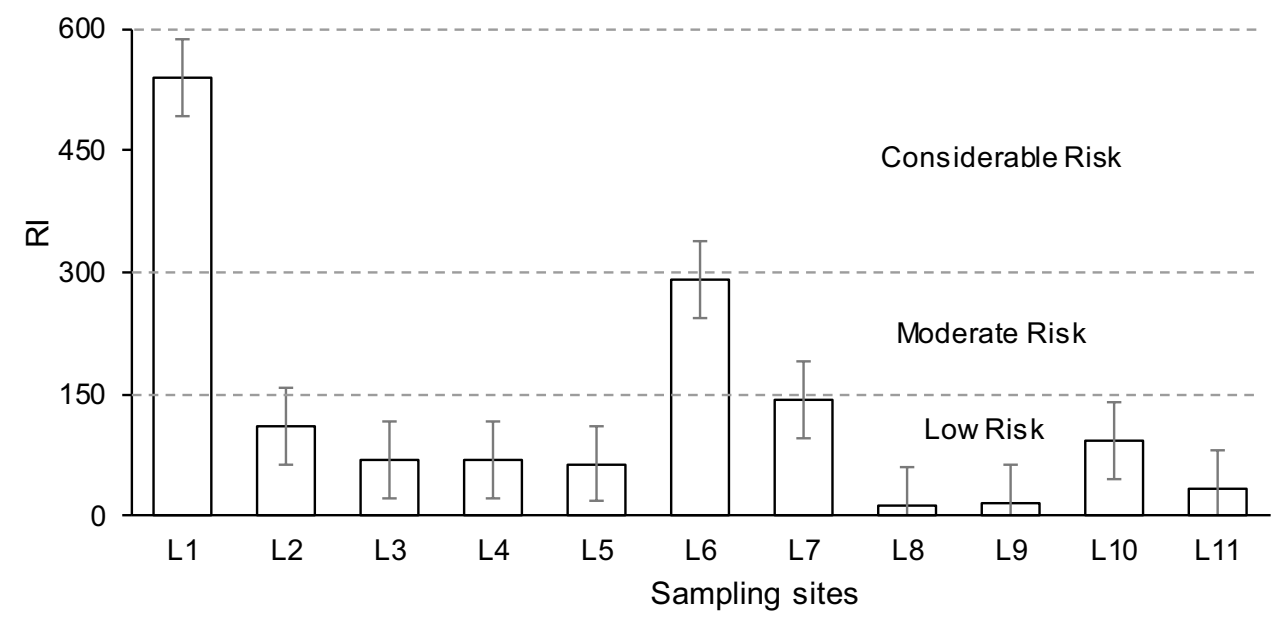

to these soils through ingestion or inhalation may result in harm to current and future residents [9].

\subsection{Non-carcinogenic and carcinogenic risks from soil metals}

The non-carcinogenic hazard index $(\mathrm{HI})$ was estimated for ingestion, dermal contact and inhalation of metal- $(\mathrm{Pb}$, $\mathrm{Cr}$ and $\mathrm{Cu}$ ) contaminated soil using Eq. 12 (Table 6). The order and intensity of non-carcinogenic hazard (expressed as $\mathrm{HQ}$ ) posed by all heavy metals through the exposure pathways is $H Q_{\text {ing }}(18.66)>H Q_{\text {dermal }}(5.97)>H Q_{\text {inh }}(1.86)$ for children and $H Q_{\text {dermal }}$ (7.98) $>H Q_{\text {ing }}(2.0)>H Q_{i n h}(0.4)$ for adults. The cumulative $H I$ in eleven sampling sites ranges from 0.68-140 (mean = 26.5) for children and 0.27-55 (mean $=10.37$ ) for adults. These values, being far greater than unity, signify a significant non-carcinogenic threat for both child and adult health. The non-carcinogenic risk to children is almost three times that of adults (Fig. 5a), which is consistent with studies conducted elsewhere $[58,59]$. The contribution by $\mathrm{Cr}, \mathrm{Pb}$, and $\mathrm{Cu}$ to non-carcinogenic health risk is $98.71 \%, 1.06 \%$ and $0.23 \%$, respectively, for both children and adults. The oral ingestion route posed the maximum contribution (70\%) to non-carcinogenic risk for adults, whereas dermal contact had the greatest contribution $(77 \%)$ for children. The contribution by inhalation was minimal ( $7 \%$ for adults, $4 \%$ for children).

Both US EPA [50] and WHO [60] categorized $\mathrm{Cr}$ as human carcinogen (group $\mathrm{A}$ ), and $\mathrm{Pb}$ as probable human carcinogen (group B). Other metals $(\mathrm{Cu}, \mathrm{Zn})$ do not pose a cancer risk. Although $\mathrm{Ni}$ contributes to some carcinogenic risk, soil Ni concentrations were far below all MPCs. Therefore, only the carcinogenicity of $\mathrm{Cr}$ and $\mathrm{Pb}$ were investigated. Table 7 shows the individual and combined cancer risk to both adults and children for $\mathrm{Cr}$ and $\mathrm{Pb}$ via ingestion, dermal and inhalation pathways. The order and intensity of carcinogenic risks posed by $\mathrm{Cr}$ through the exposure pathways is $C R_{\text {ing }}\left(1.70 \times 10^{-3}\right)>C R_{\text {inh }}$ $\left(3.66 \times 10^{-5}\right)>C R_{\text {dermal }}\left(1.26 \times 10^{-6}\right)$ for adults and $\mathrm{CR}_{\text {ing }}$ $\left(4.53 \times 10^{-2}\right)>\mathrm{CR}_{\text {inh }}\left(3.66 \times 10^{-5}\right)>\mathrm{CR}_{\text {dermal }}\left(4.71 \times 10^{-6}\right)$ for children. This indicates that oral ingestion of metals is the dominant exposure pathway for both adults and children (97.82\% and $99.91 \%$ contribution, respectively), which concur with other research $[58,59]$. The order of $\mathrm{Pb}$ contribution for children and adults was: $\mathrm{CR}_{\text {ing }}>\mathrm{CR}_{\text {dermal }}>\mathrm{CR}_{\text {inh }}$ (Table 7). Therefore, dermal contact and inhalation had a minimal contribution to cancer risk for both adults and children in the affected area.

The carcinogenic risk value $(\mathrm{Cr}$ and $\mathrm{Pb}$ combined) ranges from $4.66 \times 10^{-5}$ to $9.30 \times 10^{-3}$ (mean $1.74 \times 10^{-3}$ ) for adults and from $3.67 \times 10^{-4}$ to $2.43 \times 10^{-1}$ (mean $4.53 \times 10^{-2}$ ) for children; this implies that risks to children are 26 -fold higher than that for adult populations (Fig. 5b, Table 7). Chromium constituted the maximum carcinogenic risk $(99.98 \%$ contribution compared to $0.02 \%$ from $\mathrm{Pb}$ ). Most of the computed carcinogenic values for $\mathrm{Cr}$ are greatly in excess of the threshold limit of $1 \times 10^{-4}$, whereas the carcinogenic risk posed by $\mathrm{Pb}$ rarely exceeds $1 \times 10^{-6}$. This indicates that $\mathrm{Cr}$ should be prioritized in risk management measures in Hazaribagh former tannery area.

\subsection{Mobility of heavy metals in soil}

The average TCLP concentrations of $\mathrm{Cr}, \mathrm{Pb}, \mathrm{Zn}, \mathrm{Cu}$, and Ni were $0.05,0.09,0.37,0.06$ and $0.01 \mathrm{mg} / \mathrm{l}$, respectively (Table 8). No metal tested in this study exceeded the EPA regulatory limit for maximum concentration of contaminants for toxicity. The TCLP concentration of $\mathrm{Cr}$ comprised only $0.03 \%$ of the total $\mathrm{Cr}$ obtained from $\mathrm{HNO}_{3} / \mathrm{HCl}$ extraction. Therefore, although $\mathrm{Cr}$ is present in very high concentrations in soil, only a small fraction may be mobilized by rainwater and result in groundwater contamination. Karim et al. [15] found similar leaching behavior for soil $\mathrm{Cr}$ in the Hazaribagh area. Among all metals, Zinc was the 


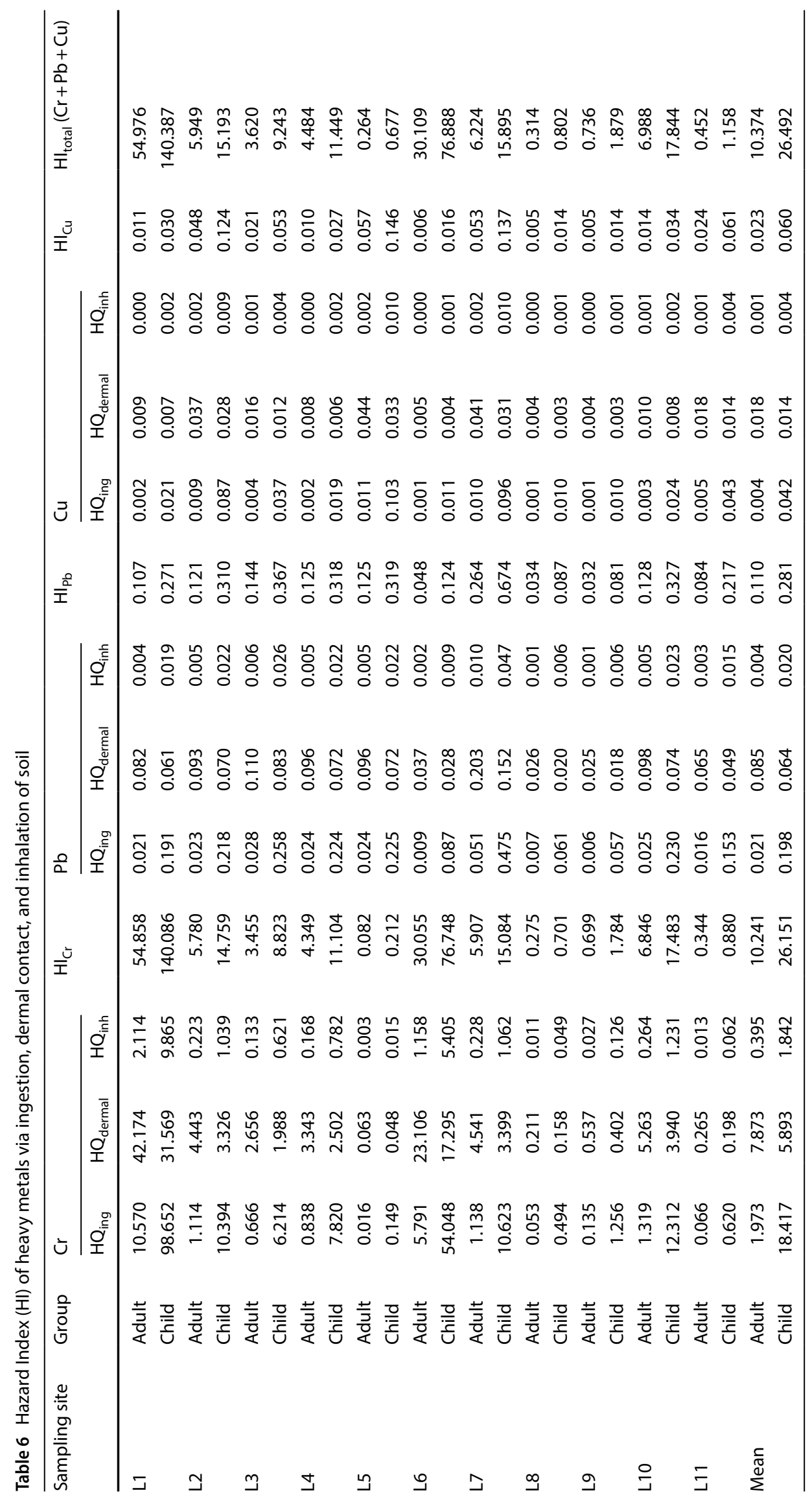


Fig. 5 a Box-whisker plot of total Hazard Index for $\mathrm{Cr}, \mathrm{Pb}$, and $\mathrm{Cu}$ in the Hazaribagh tannery area, indicating that children are at a higher risk of non-carcinogenic effects due to presence of heavy metals in the soil; and $\mathbf{b}$ Total Cancer Risk for $\mathrm{Cr}$ and $\mathrm{Pb}$. This graph also shows that children are more susceptible to developing cancer than are adults
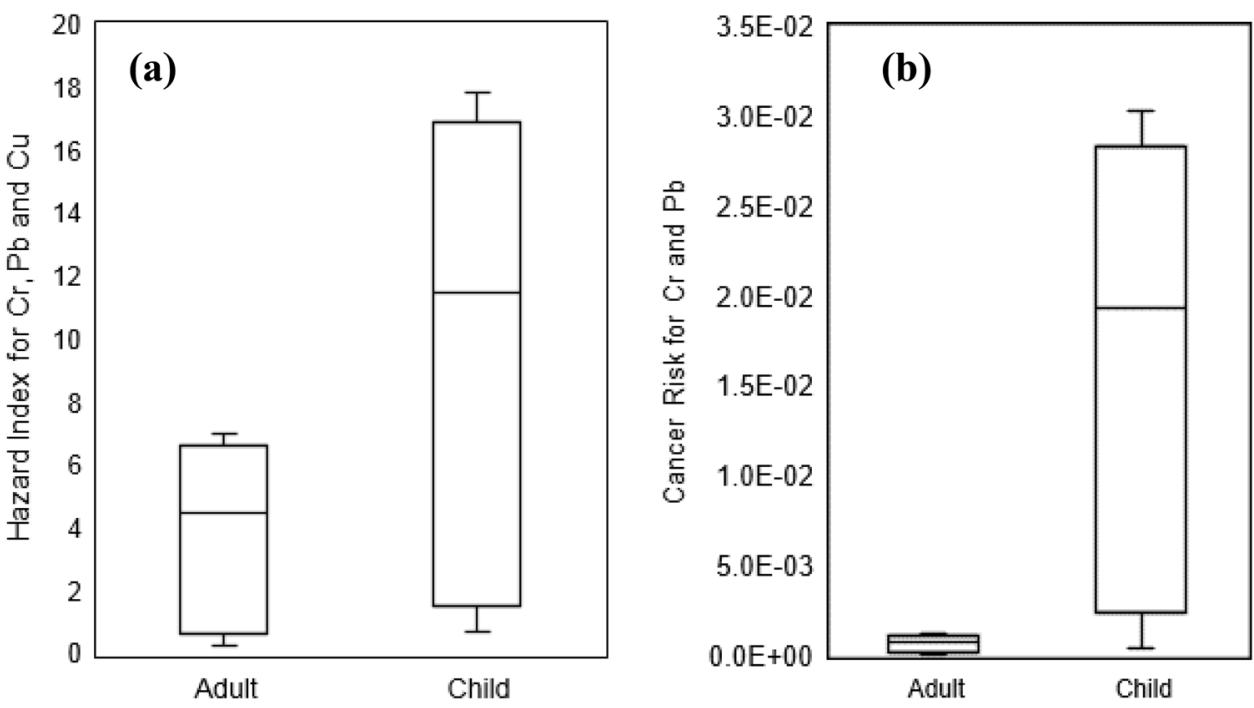

Table 7 Carcinogenic risk (CR) of heavy metals via ingestion, dermal contact, and inhalation of soil

\begin{tabular}{|c|c|c|c|c|c|c|c|c|c|c|}
\hline \multirow[t]{2}{*}{ Sampling site } & \multirow[t]{2}{*}{ Group } & \multicolumn{3}{|l|}{$\mathrm{Cr}$} & \multirow[t]{2}{*}{$\mathrm{CR}_{\text {total }(\mathrm{Cr})}$} & \multicolumn{3}{|l|}{$\mathrm{Pb}$} & \multirow[t]{2}{*}{$\mathrm{CR}_{\text {total }(\mathrm{Pb})}$} & \multirow[t]{2}{*}{$\mathrm{CR}_{\text {combined }}(\mathrm{Cr}+\mathrm{Pb})$} \\
\hline & & $\mathrm{CR}_{\text {ing }}$ & $C R_{\text {dermal }}$ & $\mathrm{CR}_{\text {inh }}$ & & $\mathrm{CR}_{\text {ing }}$ & $\mathrm{CR}_{\text {dermal }}$ & $\mathrm{CR}_{\text {inh }}$ & & \\
\hline \multirow[t]{2}{*}{ L1 } & Adult & $9.10 \mathrm{E}-03$ & $6.74 \mathrm{E}-06$ & $1.96 \mathrm{E}-04$ & $9.30 \mathrm{E}-03$ & $4.27 \mathrm{E}-08$ & $2.43 E-09$ & $4.43 E-10$ & $4.56 \mathrm{E}-08$ & $9.30 \mathrm{E}-03$ \\
\hline & Child & $2.43 \mathrm{E}-01$ & $2.52 \mathrm{E}-05$ & $1.96 \mathrm{E}-04$ & $2.43 \mathrm{E}-01$ & $1.14 \mathrm{E}-06$ & $9.11 \mathrm{E}-09$ & $4.43 E-10$ & $1.15 \mathrm{E}-06$ & $2.43 E-01$ \\
\hline \multirow[t]{2}{*}{ L2 } & Adult & $9.59 E-04$ & $7.11 \mathrm{E}-07$ & $2.06 \mathrm{E}-05$ & $9.80 E-04$ & $4.86 \mathrm{E}-08$ & $2.77 \mathrm{E}-09$ & $5.04 \mathrm{E}-10$ & $5.19 \mathrm{E}-08$ & $9.80 \mathrm{E}-04$ \\
\hline & Child & $2.56 \mathrm{E}-02$ & $2.66 \mathrm{E}-06$ & $2.06 \mathrm{E}-05$ & $2.56 \mathrm{E}-02$ & $1.30 \mathrm{E}-06$ & $1.04 \mathrm{E}-08$ & $5.04 \mathrm{E}-10$ & $1.31 E-06$ & $2.56 \mathrm{E}-02$ \\
\hline \multirow[t]{2}{*}{ L3 } & Adult & $5.73 E-04$ & $4.25 E-07$ & $1.23 \mathrm{E}-05$ & $5.86 \mathrm{E}-04$ & $5.75 E-08$ & $3.28 \mathrm{E}-09$ & $5.97 \mathrm{E}-10$ & $6.14 \mathrm{E}-08$ & $5.86 \mathrm{E}-04$ \\
\hline & Child & $1.53 E-02$ & $1.59 E-06$ & $1.23 E-05$ & $1.53 E-02$ & $1.53 E-06$ & $1.23 E-08$ & $5.97 \mathrm{E}-10$ & $1.55 E-06$ & $1.53 E-02$ \\
\hline \multirow[t]{2}{*}{ L4 } & Adult & $7.21 \mathrm{E}-04$ & $5.35 \mathrm{E}-07$ & $1.55 \mathrm{E}-05$ & $7.37 E-04$ & $4.99 \mathrm{E}-08$ & $2.85 \mathrm{E}-09$ & $5.18 \mathrm{E}-10$ & $5.33 \mathrm{E}-08$ & $7.37 \mathrm{E}-04$ \\
\hline & Child & $1.92 \mathrm{E}-02$ & $2.00 E-06$ & $1.55 \mathrm{E}-05$ & $1.93 E-02$ & $1.33 \mathrm{E}-06$ & $1.07 \mathrm{E}-08$ & $5.18 \mathrm{E}-10$ & $1.34 \mathrm{E}-06$ & $1.93 E-02$ \\
\hline \multirow[t]{2}{*}{ L5 } & Adult & $1.37 \mathrm{E}-05$ & $1.02 \mathrm{E}-08$ & $2.95 \mathrm{E}-07$ & $1.40 \mathrm{E}-05$ & $5.01 E-08$ & $2.86 \mathrm{E}-09$ & $5.20 \mathrm{E}-10$ & $5.35 E-08$ & $1.41 \mathrm{E}-05$ \\
\hline & Child & $3.65 E-04$ & $3.80 \mathrm{E}-08$ & $2.95 \mathrm{E}-07$ & $3.66 \mathrm{E}-04$ & $1.34 \mathrm{E}-06$ & $1.07 E-08$ & $5.20 \mathrm{E}-10$ & $1.35 E-06$ & $3.67 \mathrm{E}-04$ \\
\hline \multirow[t]{2}{*}{ L6 } & Adult & $4.99 E-03$ & $3.69 E-06$ & $1.07 \mathrm{E}-04$ & $5.10 E-03$ & $1.95 E-08$ & $1.11 \mathrm{E}-09$ & $2.03 E-10$ & $2.08 \mathrm{E}-08$ & $5.10 \mathrm{E}-03$ \\
\hline & Child & $1.33 \mathrm{E}-01$ & $1.38 \mathrm{E}-05$ & $1.07 E-04$ & $1.33 \mathrm{E}-01$ & $5.21 \mathrm{E}-07$ & $4.16 \mathrm{E}-09$ & $2.03 E-10$ & $5.25 \mathrm{E}-07$ & $1.33 \mathrm{E}-01$ \\
\hline \multirow[t]{2}{*}{ L7 } & Adult & $9.80 \mathrm{E}-04$ & $7.26 \mathrm{E}-07$ & $2.11 E-05$ & $1.00 \mathrm{E}-03$ & $1.06 \mathrm{E}-07$ & $6.04 \mathrm{E}-09$ & $1.10 \mathrm{E}-09$ & $1.13 \mathrm{E}-07$ & $1.00 \mathrm{E}-03$ \\
\hline & Child & $2.61 \mathrm{E}-02$ & $2.72 \mathrm{E}-06$ & $2.11 E-05$ & $2.62 \mathrm{E}-02$ & $2.83 E-06$ & $2.26 \mathrm{E}-08$ & $1.10 \mathrm{E}-09$ & $2.85 E-06$ & $2.62 \mathrm{E}-02$ \\
\hline \multirow[t]{2}{*}{ L8 } & Adult & $4.55 \mathrm{E}-05$ & $3.37 \mathrm{E}-08$ & $9.80 E-07$ & $4.65 \mathrm{E}-05$ & $1.37 \mathrm{E}-08$ & $7.78 \mathrm{E}-10$ & $1.42 \mathrm{E}-10$ & $1.46 \mathrm{E}-08$ & $4.66 \mathrm{E}-05$ \\
\hline & Child & $1.21 \mathrm{E}-03$ & $1.26 \mathrm{E}-07$ & $9.80 E-07$ & $1.22 \mathrm{E}-03$ & $3.64 \mathrm{E}-07$ & $2.91 \mathrm{E}-09$ & $1.42 \mathrm{E}-10$ & $3.67 \mathrm{E}-07$ & $1.22 \mathrm{E}-03$ \\
\hline \multirow[t]{2}{*}{ L9 } & Adult & $1.16 \mathrm{E}-04$ & $8.58 \mathrm{E}-08$ & $2.49 E-06$ & $1.18 \mathrm{E}-04$ & $1.28 \mathrm{E}-08$ & $7.29 E-10$ & $1.33 \mathrm{E}-10$ & $1.37 \mathrm{E}-08$ & $1.18 \mathrm{E}-04$ \\
\hline & Child & $3.09 E-03$ & $3.21 \mathrm{E}-07$ & $2.49 E-06$ & $3.09 E-03$ & $3.41 \mathrm{E}-07$ & $2.73 E-09$ & $1.33 \mathrm{E}-10$ & $3.44 \mathrm{E}-07$ & $3.09 E-03$ \\
\hline \multirow[t]{2}{*}{ L10 } & Adult & $1.14 \mathrm{E}-03$ & $8.42 \mathrm{E}-07$ & $2.44 \mathrm{E}-05$ & $1.16 \mathrm{E}-03$ & $5.13 E-08$ & $2.92 \mathrm{E}-09$ & $5.32 \mathrm{E}-10$ & $5.47 \mathrm{E}-08$ & $1.16 \mathrm{E}-03$ \\
\hline & Child & $3.03 E-02$ & $3.15 E-06$ & $2.44 \mathrm{E}-05$ & $3.03 E-02$ & $1.37 E-06$ & $1.09 \mathrm{E}-08$ & $5.32 \mathrm{E}-10$ & $1.38 \mathrm{E}-06$ & $3.03 E-02$ \\
\hline \multirow[t]{2}{*}{ L11 } & Adult & $5.72 \mathrm{E}-05$ & $4.24 \mathrm{E}-08$ & $1.23 E-06$ & $5.85 \mathrm{E}-05$ & $3.42 \mathrm{E}-08$ & $1.95 \mathrm{E}-09$ & $3.55 \mathrm{E}-10$ & $3.65 E-08$ & $5.85 \mathrm{E}-05$ \\
\hline & Child & $1.52 \mathrm{E}-03$ & $1.59 \mathrm{E}-07$ & $1.23 E-06$ & $1.53 E-03$ & $9.11 \mathrm{E}-07$ & $7.29 E-09$ & $3.55 \mathrm{E}-10$ & $9.18 \mathrm{E}-07$ & $1.53 E-03$ \\
\hline \multirow[t]{2}{*}{ Mean } & Adult & $1.70 \mathrm{E}-03$ & $1.26 \mathrm{E}-06$ & $3.66 \mathrm{E}-05$ & $1.74 \mathrm{E}-03$ & $4.42 \mathrm{E}-08$ & $2.52 \mathrm{E}-09$ & $4.59 E-10$ & $4.72 \mathrm{E}-08$ & $1.74 \mathrm{E}-03$ \\
\hline & Child & $4.53 \mathrm{E}-02$ & $4.71 \mathrm{E}-06$ & $3.66 \mathrm{E}-05$ & $4.53 \mathrm{E}-02$ & $1.18 \mathrm{E}-06$ & $9.43 \mathrm{E}-09$ & $4.59 \mathrm{E}-10$ & $1.19 \mathrm{E}-06$ & $4.53 \mathrm{E}-02$ \\
\hline
\end{tabular}

most mobile with a relatively higher concentration in the leaching test $(0.37 \mathrm{mg} / \mathrm{L})$, and also a higher mobilized fraction (4.98\%) compared to the acid extraction concentration. Similarly, high TCLP concentration was found for $\mathrm{Pb}$
(0.09 mg/l), which corresponds to a $6.13 \%$ mobilized fraction. Previous studies have also reported $\mathrm{Zn}$ and $\mathrm{Pb}$ to be highly mobile metals [61]. These results indicate that $\mathrm{Pb}$ and $\mathrm{Zn}$ pose a potential threat for groundwater pollution. According to leaching potential, the order of heavy 
Table 8 Leaching of $\mathrm{Cr}, \mathrm{Pb}, \mathrm{Zn}$, $\mathrm{Cu}$ and Ni from TCLP leaching

\begin{tabular}{lllll}
\hline Heavy metals & Average $(\mathrm{mg} / \mathrm{l})$ & $\begin{array}{l}\text { Standard } \\
\text { deviation }\end{array}$ & $\begin{array}{l}\text { Leaching (\%) (relative to } \\
\mathrm{HNO}_{3} / \mathrm{HCl} \text { extraction) }\end{array}$ & $\begin{array}{l}\text { USEPA regula- } \\
\text { tory limit } \\
(\mathrm{mg} / \mathrm{l})\end{array}$ \\
\hline $\mathrm{Cr}$ & 0.05 & 0.02 & 0.03 & 5 \\
$\mathrm{~Pb}$ & 0.09 & 0.04 & 6.13 & 5 \\
$\mathrm{Zn}$ & 0.37 & 0.31 & 4.98 & - \\
$\mathrm{Cu}$ & 0.06 & 0.04 & 1.64 & - \\
$\mathrm{Ni}$ & 0.01 & 0.01 & 4.41 & - \\
\hline
\end{tabular}

${ }^{a}$ Environmental Protection Agency (EPA) 40 CFR $§$ 261.24-Toxicity characteristic

\begin{tabular}{lrrrlll}
\hline Metals & \multicolumn{1}{l}{ L4 } & \multicolumn{1}{l}{ L7 } & L10 & $\begin{array}{l}\text { Safe limit (FAO/ } \\
\text { WHO) [63] }\end{array}$ & $\begin{array}{l}\text { Safe limit } \\
\text { (India) [64] }\end{array}$ & $\begin{array}{l}\text { Safe limit } \\
\text { (China) } \\
\text { [65] }\end{array}$ \\
\hline $\mathrm{Cr}$ & $6.1 \pm 0.09$ & $178.45 \pm 0.80$ & $10.1 \pm 0.14$ & 5 & 20 & 0.5 \\
$\mathrm{~Pb}$ & $18.6 \pm 0.15$ & $14.2 \pm 0.23$ & $8.8 \pm 0.09$ & 5 & 2.5 & 0.3 \\
$\mathrm{Zn}$ & $66.9 \pm 0.10$ & $556.45 \pm 1.10$ & $72.6 \pm 0.49$ & 60 & 50 & - \\
$\mathrm{Cu}$ & $13.2 \pm 0.42$ & $27.25 \pm 0.28$ & $10.3 \pm 0.07$ & 40 & 30 & - \\
$\mathrm{Ni}$ & $1.9 \pm 0.07$ & $3.5 \pm 0.05$ & $1.7 \pm 0.03$ & 20 & 1.5 & - \\
\hline
\end{tabular}

Table 9 Heavy metal content of edible part of vine spinach grown on Hazaribagh soil (All quantities in $\mathrm{mg} / \mathrm{kg}$ )

Table 10 Transfer factor of heavy metals in vine spinach grown on contaminated soil

Hazaribagh soil.

\subsection{Heavy metals in plants}

Heavy metal concentrations in edible parts of spinach were variable, with tissue from $L 7$ having the highest concentration (Table 9). The concentration of heavy metals in vegetables correlates positively to corresponding concentrations in soil in the sampling locations (Table 3 ). Concentrations of $\mathrm{Pb}, \mathrm{Cr}$, and $\mathrm{Zn}$ in plant tissue were several orders of magnitude in excess of safe limits. Although the soil $\mathrm{Zn}$ concentration is within acceptable limits, the high concentration in vine spinach $(66.9-556.45 \mathrm{mg} / \mathrm{kg}$ ) supports earlier findings that $\mathrm{Zn}$ bioavailability and mobility is high. Tissue $\mathrm{Cu}$ and $\mathrm{Ni}$ concentrations were generally below FAO/WHO acceptable limits, with only $\mathrm{Ni}$ exceeding the Indian limit $(1.5 \mathrm{mg} / \mathrm{kg})$. These results show that, although soil metal concentrations are within acceptable limits, vegetables grown on the same soil may accumulate them to levels beyond safe edible limits. Therefore, consuming vegetables grown in the study area may impart harmful impacts on human health. Amount of metal uptake and accumulation is likely to vary with plant species.

Transfer of metals from soil into different plant parts can be assessed using the transfer factor (TF). The highest value of $T F$ for $\mathrm{Pb}$ was 2.780 (Mean $T F=1.064$ ), indicating that it is the most mobile among all heavy metals tested (Table 10). Although it is typically reported that $\mathrm{Pb}$ is scarcely soluble in soil, especially at basic $\mathrm{pH}$ values, the

\begin{tabular}{llllll}
\hline $\begin{array}{l}\text { Sampling } \\
\text { location }\end{array}$ & TF & \multicolumn{3}{l}{} \\
\cline { 2 - 6 } & $\mathrm{Cr}$ & $\mathrm{Pb}$ & $\mathrm{Zn}$ & $\mathrm{Cu}$ & $\mathrm{Ni}$ \\
\hline L4 & 0.003 & 0.304 & 0.220 & 0.227 & 0.225 \\
$\mathrm{L7}$ & 0.072 & 0.109 & 0.538 & 0.091 & 0.286 \\
L10 & 0.046 & 2.780 & 0.409 & 2.503 & 0.787 \\
Mean & 0.040 & 1.064 & 0.389 & 0.940 & 0.433 \\
\hline
\end{tabular}

high concentration in plants could be a result of historical accumulation that has occurred over the years. During our sampling, soil pH was in the range 6.9-8.3, but there is evidence that soil $\mathrm{pH}$ was less than 4 when the tanneries were operational [25]. Highly acidic wastes discharged in the environment, and microbial decomposition of organic matter could have resulted in low $\mathrm{pH}$ in the soil and mobilized $\mathrm{Pb}$, resulting in increased plant uptake. Other studies have found high transfer of $\mathrm{Pb}$ to plants grown on contaminated soil, and that leafy vegetables accumulated higher quantities of $\mathrm{Pb}$ than did fruit plants $[16,62]$. Copper was the second most mobile metal, with a maximum $T F$ of 2.503 (mean value $=0.940$ ). On the other hand, $\mathrm{Cr}$ had the lowest bioavailability (mean $T F=0.040$ ). This may be due to the tendency of $\mathrm{Cr}$ to bind strongly with soil colloids [39]. The tendency of metal transfer from soil to plants follows the order: $\mathrm{Pb}>\mathrm{Cu}>\mathrm{Ni}>\mathrm{Zn}>\mathrm{Cr}$. These trends are similar to investigations elsewhere [39]. Based on the results of this study, it is strongly recommended 
that inhabitants of Hazaribagh, Dhaka should avoid cultivating any edible plants in the soil to reduce exposure.

\section{Conclusions}

Decades of unregulated industrial activities by tanneries in the Hazaribagh area of Dhaka have taken a significant toll on the surrounding environment. In this study, using environmental and health indices such as $C F, C_{d e g}$ PLI, and $I_{\text {geo, }}$ it was shown that more than half of the area was highly or moderately contaminated with $\mathrm{Cr}, \mathrm{Pb}, \mathrm{Zn}$, and $\mathrm{Cu}$. Significant enrichment of $\mathrm{Cr}$ occurred presumably due to the operation of tanning industries. High soil $\mathrm{Cr}$ and $\mathrm{Cu}$ concentrations pose a significant ecological risk. The total cancer risk for $\mathrm{Cr}$ and $\mathrm{Pb}$ exceeded the universally recognized safe limits $\left(1 \times 10^{-4}\right)$, rendering the area unsafe for habitation. The potential for leaching of $\mathrm{Pb}$ and $\mathrm{Zn}$ to groundwater is also a major concern. The concentrations of $\mathrm{Pb}, \mathrm{Cr}$, and $\mathrm{Zn}$ in edible parts of spinach exceeded safe limits, indicating the potential for significant enrichment in the food chain. There is a general perception that the Hazaribagh area has been 'cleaned' since the tanneries have been relocated; this may be partly due to the slightly higher dissolved oxygen levels recently observed in the adjacent Buriganga river [66]. In this study, analysis of soil has confirmed that this might not be the case, and mitigation measures are necessary in order to render the area safe for living. Soil remediation measures must be undertaken before initiating residential and commercial development projects. Some cost-effective, environmentfriendly remediation techniques include phytoremediation (with or without chelating agents), immobilization of heavy metals by applying chemical agents, and soil washing using chemical solutions [62]. The spatial distribution of heavy metal contamination and associated risks presented in this study will allow policymakers to pinpoint areas of intervention for remediation.

Acknowledgement The authors acknowledge Ehosan Habib of the Department of Civil Engineering and the staff of the Environmental Engineering Laboratory of BUET for their assistance in analyzing samples. The authors also wish to thank the three reviewers for their useful comments and suggestions.

\section{Compliance with ethical standards}

Conflict of interest The author(s) declare that they have no competing interests.

\section{References}

1. Chen HY, Teng YG, Lu SJ, Wang YY, Wang JS (2015) Contamination features and health risk of soil heavy metals in China. Sci Total Environ 512-513:143-153. https://doi.org/10.1016/j.scito tenv.2015.01.025

2. Whitehead PG, Bussi G, Peters R, Hossain MA, Softley L, Shawal S, Jin L, Rampley CPN, Holdship P, Hope R, Alabaster G (2019) Modelling heavy metals in the Buriganga river system, Dhaka, Bangladesh: impacts of tannery pollution control. Sci Total Environ 697:134090. https://doi.org/10.1016/j.scitotenv.2019.13409 0

3. Joy OC, Uchenna AP (2017) Accumulation and risk assessment of heavy metal contents in school playgrounds in Port Harcourt Metropolis, Rivers State, Nigeria. J Chem Health Safety 24:11-22. https://doi.org/10.1016/j.jchas.2017.01.002

4. Pajević S, Arsenov D, Nikolić N, Borišev M, Orčić D, Župunski M, Dukić NM (2018) Heavy metal accumulation in vegetable species and health risk assessment in Serbia. Environ Monit Assess 190(459):1-14. https://doi.org/10.1007/s10661-018-6743-y

5. Ali Z, Malik RN, Shinwari ZK, Qadir A (2015) Enrichment, risk assessment, and statistical apportionment of heavy metals in tannery-affected areas. Int J Environ Sci Technol 12:537-550. https://doi.org/10.1007/s13762-013-0428-4

6. Shao M, Zhu Y, Hao R, Yu Z, Song M (2018) The health hazards of potentially toxic metals in the daily diets of adults and children from a mining and smelting region (Hezhang County) in southwestern China. Environ Monit Assess 190:432. https://doi. org/10.1007/s10661-018-6816-y

7. Juel MAI, Chowdhury ZUM, Mizan A, Alam MS (2016) Toxicity and environmental impact assessment of metals contaminated soil of Hazaribagh Tannery Area. In: International conference on advances in civil engineering, pp 21-23

8. Barrett HA, Ferraro A, Burnette C, Meyer A, Krekeler MPS (2012) An investigation of heavy metal content from disposable batteries of non-U.S. origin from Butler County, Ohio: an environmental assessment of a segment of a waste stream. J Power Sources 206:414-420. https://doi.org/10.1016/j.jpowsour.2012.01.008

9. Kabir E, Ray S, Kim KH, Yoon HO, Jeon EC, Kim YS, Cho YS, Yun ST, Brown RJC (2012) Current status of trace metal pollution in soils affected by industrial activities. Sci World J. https://doi. org/10.1100/2012/916705

10. Hassan S, Hakimeh O, Daryoush A, Effatosadat AM (2012) Lead contamination in soil and vegetation of areas surrounding different mining activity zones in Kerman province of Iran. African J Biot 11:14146-14152. https://doi.org/10.5897/AJB11.3613

11. Zahid A, Balke KD, Hassan MQ, Flegr M (2006) Evaluation of aquifer environment under Hazaribagh leather processing zone of Dhaka city. Environ Geol 50:495-504. https://doi.org/10.1007/ s00254-006-0225-1

12. Bhuiyan MAH, Suruvi NI, Dampare SB, Islam MA, Quraishi SB, Ganyaglo S, Suzuki S (2011) Investigation of the possible sources of heavy metal contamination in lagoon and canal water in the tannery industrial area in Dhaka, Bangladesh. Environ Monit Assess 175:633-649. https://doi.org/10.1007/s1066 1-010-1557-6

13. Alam MS, Han B, Mizan A, Pichtel J (2019) Assessment of soil and groundwater contamination at a former Tannery district in Dhaka, Bangladesh. Environ Geochem Health. https://doi. org/10.1007/s10653-019-00457-6

14. Mizan A, Zohra FT, Ahmed S, Nurnabi M, Alam MZ (2016) Low cost adsorbent for mitigation of water pollution caused by tannery effluents at Hazaribagh. Bangladesh J Sci Ind Res. 51:215220. https://doi.org/10.3329/bjsir.v51i3.29433 
15. Karim MR, Manshoven S, Islam MR, Gascon JA, Ibarra M, Diels L, Rahman MM (2013) Assessment of an urban contaminated site from tannery industries in Dhaka city, Bangladesh. J Hazard Toxic Radioact Waste 17:52-61. https://doi.org/10.1061/(ASCE) HZ.2153-5515.0000139

16. Muchuweti M, Birkett JW, Chinyanga E, Zvauya R, Scrimshaw MD, Lester JN (2006) Heavy metal content of vegetables irrigated with mixtures of wastewater and sewage sludge in Zimbabwe: implications for human health. Agric Ecosyst Environ 112:41-48. https://doi.org/10.1016/j.agee.2005.04.028

17. Chang CY, Yu HY, Chen JJ, Li FB, Zhang HH, Liu CP (2014) Accumulation of heavy metals in leaf vegetables from agricultural soils and associated potential health risks in the Pearl River Delta, South China. Environ Monit Assess 186:1547-1560. https ://doi.org/10.1007/s10661-013-3472-0

18. Beyersmann D, Hartwig A (2008) Carcinogenic metal compounds: recent insight into molecular and cellular mechanisms. Arch Toxicol 82:493-512. https://doi.org/10.1007/s0020 4-008-0313-y

19. Uddin ANMM, Ahmed SA (2018) Heavy metal contamination of soil and health hazards among the residents of tannery industrial area. Anwer Khan Mod Med Coll J. 9:39-43. https://doi. org/10.3329/akmmcj.v9i1.35823

20. Rahaman A, Afroze JS, Bashar K, Ali MF, Hosen MR (2016) A comparative study of heavy metal concentration in different layers of tannery vicinity soil and near agricultural soil. Am J Analy Chem 7:880-889. https://doi.org/10.4236/ajac.2016.712075

21. Latif SA, Afroj D, Hossain SM, Uddin MS, Islam MA, Begum $K$, Oura Y, Ebihara M, Katada M (2009) Determination of toxic trace elements in foodstuffs, soils and sediments of Bangladesh using instrumental neutron activation analysis technique. Bull Environ Contam Toxicol 82:384-388. https://doi.org/10.1007/s0012 8-008-9621-4

22. Mondol MN, Asia A, Chamon AS, Faiz SMA (2017) Contamination of soil and plant by the Hazaribagh tannery industries. J. Asiat Soc. Bangladesh Sci. 43:207-222

23. Khan FE, Jolly YN, Islam GMR, Akhter S, Kabir J (2014) Contamination status and health risk assessment of trace elements in foodstuffs collected from the Buriganga River embankments, Dhaka, Bangladesh. Int J Food Contam 1:1-8. https://doi.org/10.1186/ s40550-014-0001-z

24. BBS (Bangladesh Bureau of Statistics), (2011) Bangladesh population and housing census

25. Shams KM, Tichy G, Sager M, Peer T, Bashar A, Jozic M (2009) Soil contamination from tannery wastes with emphasis on the fate and distribution of tri- and hexavalent chromium. Water Air Soil Pollut 199:123-137. https://doi.org/10.1007/s11270-008-9865-y

26. ISO 11466, International Standard (1995) Soil quality - extraction of trace elements soluble in Aqua Regia. International Organization for Standardization, Genève

27. Choudhury MR, Islam MS, Ahmed ZU, Nayar F (2015) Phytoremediation of heavy metal contaminated buriganga riverbed sediment by indian mustard and marigold plants. Environ Prog Sustain Energy 35:117-124. https://doi.org/10.1002/ep.12213

28. APHA (1992) Standard Methods 3111, Metals by atomic absorption spectrometry. Standard methods for the examination of water and wastewater, American Public Health Association, American Water Works Association/Water Environment Federation

29. APHA (2017) Standard Methods 3030, Preliminary treatment of samples, standard methods for the examination of water and wastewater. American Public Health Association/American Water Works Association, Water Environment Federation. https ://doi.org/10.2105/smww.2882.041
30. USEPA (1992) Toxicity Characteristic Leaching Procedure (TCLP). Publication SW846. Method 1311, US Environmental Protection Agency, Washington D.C

31. Turekian KK, Wedepohl KH (1961) Distribution of the elements in some major units of the earth's crust. Bull Geol Soc Am 72:175-192

32. Kabata-Pendias A, Pendias H (2001) Trace elements in soils and plants, 3rd edn. CRC Press, Boca Raton

33. Hakanson $L$ (1980) An ecological risk index for aquatic pollution control. a sedimentological approach. Water Res 14:975-1001. https://doi.org/10.1016/0043-1354(80)90143-8

34. Mugoša $B$, Đurović $D$, Nedović-Vuković $M$, Barjaktarović-Labović S, Vrvić M (2016) Assessment of ecological risk of heavy metal contamination in coastal municipalities of montenegro. Int $J$ Environ Res Public Health 13:393. https://doi.org/10.3390/ijerp h13040393

35. Tomlinson DL, Wilson JG, Harris CR, Jeffrey DW (1980) Problems in the assessment of heavy-metal levels in estuaries and the formation of a pollution index. Helgoländer Meeresuntersuchungen. 33:566-575. https://doi.org/10.1007/BF02414780

36. Muller G (1969) Index of geoaccumulation in sediments of the Rhine River. Geo J 2:108-118

37. Shakeri A, Shakeri R, Mehrabi B (2016) Contamination, toxicity and risk assessment of heavy metals and metalloids in sediments of Shahid Rajaie Dam, Sefidrood and Shirinrood Rivers, Iran. Environ Earth Sci 75:679. https://doi.org/10.1007/s1266 5-016-5461-4

38. Xie Z, Jiang $Y$, Zhang H, Wang D, Qi S, Du Z, Zhang H (2016) Assessing heavy metal contamination and ecological risk in Poyang Lake area, China. Environ Earth Sci 75:549

39. Gebrekidan A, Weldegebriel Y, Hadera A, Bruggen BV (2013) Toxicological assessment of heavy metals accumulated in vegetables and fruits grown in Ginfel river near Sheba Tannery, Tigray, Northern Ethiopia. Ecotoxicol Environ Saf 95:171-178. https:// doi.org/10.1016/j.ecoenv.2013.05.035

40. USDOE (2011) The risk assessment information system (RAIS). U.S. Department of Energy's Oak Ridge Operations Office (ORO)

41. Luo XS, Ding J, Xu B, Wang YJ, Li HB, Yu S (2012) Incorporating bioaccessibility into human health risk assessments of heavy metals in urban park soils. Sci Total Environ 424:88-96. https:// doi.org/10.1016/j.scitotenv.2012.02.053

42. Proshad R, Kormoker T, Islam SM, Hanif MA, Chandra K (2018) Chronic exposure assessment of toxic elements from agricultural soils around the industrial areas of Tangail district, Bangladesh. Arch Agri Environ Sci 3:317-336. https://doi.org/10.26832 /24566632.2018.030401

43. USEPA (1989) Risk assessment guidance for Superfund. Volume I: human health evaluation manual (Part A), Interim Final. U.S. Environmental Protection Agency, Office of Emergency and Remedial Response. EPA/540/1-89/002

44. USEPA (1997) Exposure factors handbook. Washington, DC: U.S. Environmental Protection Agency, Office of Research and Development. EPA/600/P-95/002Fa

45. USEPA (2001) Risk assessment guidance for superfund: volume III - part A, process for conducting probabilistic risk assessment, 20460. Washington, DC: U.S. Environmental Protection Agency, Office of Emergency and Remedial Response. EPA 540-R-02-002

46. Zheng N, Liu JH, Wang QC, Liang ZZ (2010) Health risk assessment of heavy metal exposure to street dust in the zinc smelting district. Northeast China Sci Total Environ. 408:726-733. https:// doi.org/10.1016/j.scitotenv.2009.10.075

47. Huang YN, Dang F, Li M et al (2019) Environmental and human health risks from metal exposures nearby a $\mathrm{Pb}-\mathrm{Zn}-\mathrm{Ag}$ mine. Sci Total Environ China. https://doi.org/10.1016/j.scito tenv.2019.134326 
48. Cao S, Duan X, Zhao X, Ma J, Dong T, Huang N, Sun C, He B, Wei $\mathrm{F}$ (2014) Health risks from the exposure of children to $\mathrm{As}, \mathrm{Se}, \mathrm{Pb}$ and other heavy metals near the largest coking plant in China. Sci Total Environ 472:1001-1009

49. USEPA (2011) Screening Levels (RSL) for chemical contaminants at superfund sites. U.S. Environmental Protection Agency

50. USEPA (2002) Supplemental guidance for developing soil screening levels for superfund sites. U.S. Environmental Protection Agency. pp 4-24. OSWER 9355

51. Ministry of Environmental Protection of the People's Republic of China, (2018). Soil environmental quality, risk control standard for soil contamination of agricultural land standard (GB156182018), China

52. Ministry of the Environment, Finland, (2007). Government Decree on the Assessment of Soil Contamination and Remediation Needs, 214

53. Abedin MJ, Akter S, Arafin SAK (2015) Chromium toxicity in soil around tannery area, Hazaribagh, Dhaka, Bangladesh, and its impacts on environment as well as human health. Int J Inno Res Adv Eng (IJIRAE) 2(4):119

54. Saha GC, Ali MA (2001) Groundwater contamination in Dhaka city from tannery waste. J Civ Eng Inst Eng Bangladesh 29:151-165

55. Paul D, Choudhary B, Gupta T, Jose MT (2015) Spatial distribution and the extent of heavy metal and hexavalent chromium pollution in agricultural soils from Jajmau, India. Environ Earth Sci 73:3565-3577. https://doi.org/10.1007/s12665-014-3642-6

56. Bini C, Maleci L, Romanin A (2008) The chromium issue in soils of the leather tannery district in Italy. J Geochem Explor 96(2):194202. https://doi.org/10.1016/j.gexplo.2007.03.008

57. Covington AD (2009) Tanning chemistry the science of leather. Royal Society of Chemistry, UK, 1st edition, 372-380

58. Ma W, Tai L, Qiao Z, Zhong L, Wang Z, Fu K, Chen G (2018) Contamination source apportionment and health risk assessment of heavy metals in soil around municipal solid waste incinerator: a case study in North China. Sci Total Environ 631-632:348-357. https://doi.org/10.1016/j.scitotenv.2018.03.011

59. Zeng S, Ma J, Yang Y, Zhang S, Liuc GJ, Chen F (2019) Spatial assessment of farmland soil pollution and its potential human health risks in China. Sci Total Environ 687:642-653. https://doi. org/10.1016/j.scitotenv.2019.05.291

60. WHO (2011) Agents classified by the iarc monographs. World Health Organization, International Agency for Research on Cancer (IARC)

61. Rahman SH, Khanam D, Adyel TM, Islam MS, Ahsan MA, Akbor MA (2012) Assessment of Heavy Metal contamination of agricultural soil around dhaka export processing zone (DEPZ), Bangladesh: implication of seasonal variation and indices. Appl Sci 2:584-601. https://doi.org/10.3390/app2030584

62. Wuana RA, Okieimen FE (2011) Heavy metals in contaminated soils: a review of sources, chemistry, risks and best available strategies for remediation. Int Schol Res Notices. https://doi. org/10.5402/2011/402647

63. FAO/WHO (1999) Expert committee on food additives, summary and conclusions. In: 53rd Meeting, Rome, 1-10

64. Awasthi SK (2000) Prevention of food adulteration Act No. 37 of 1954. Central and State rules as amended for 1999 (3rd ed.). Ashoka Law House, New Delhi

65. Chinese national food standards (2017) National Food Safety Standard for Maximum Levels of Contaminants in Foods (GB 2762-2017), China

66. Rashedul Islam MR (2018) Effects of relocation of tannery industries from Hazaribagh on water quality of Buriganga river. Dissertation, Bangladesh University of Engineering and Technology

Publisher's Note Springer Nature remains neutral with regard to jurisdictional claims in published maps and institutional affiliations. 